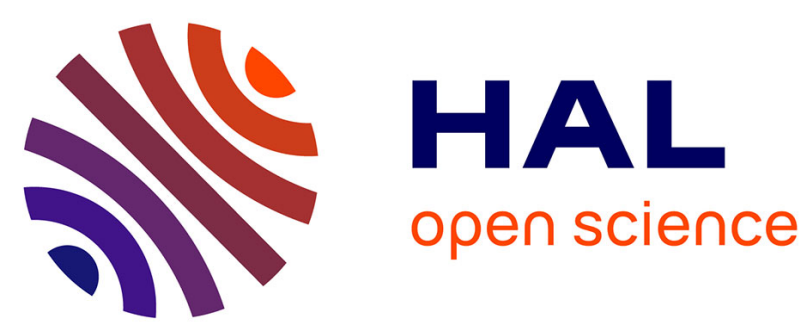

\title{
Anisyl and ferrocenyl adducts of methylenepyran-containing $\beta$-diketone: Synthesis, spectral, structural, and redox properties
}

Néstor Novoa, Thierry Roisnel, Vincent Dorcet, Jean-René Hamon, David Carillo, Carolina Manzur, Françoise Robin-Le Guen, Nolwenn Cabon

\section{To cite this version:}

Néstor Novoa, Thierry Roisnel, Vincent Dorcet, Jean-René Hamon, David Carillo, et al.. Anisyl and ferrocenyl adducts of methylenepyran-containing $\beta$-diketone: Synthesis, spectral, structural, and redox properties. Journal of Organometallic Chemistry, 2014, 762, pp.19-28. 10.1016/j.jorganchem.2014.03.029 . hal-01058192

HAL Id: hal-01058192

https://hal-univ-rennes1.archives-ouvertes.fr/hal-01058192

Submitted on 26 Aug 2014

HAL is a multi-disciplinary open access archive for the deposit and dissemination of scientific research documents, whether they are published or not. The documents may come from teaching and research institutions in France or abroad, or from public or private research centers.
L'archive ouverte pluridisciplinaire HAL, est destinée au dépôt et à la diffusion de documents scientifiques de niveau recherche, publiés ou non, émanant des établissements d'enseignement et de recherche français ou étrangers, des laboratoires publics ou privés. 


\section{Anisyl and Ferrocenyl Adducts of Methylenepyran-Containing $\beta$ - Diketone: Synthesis, Spectral, Structural, and Redox Properties}

\section{Néstor Novoa $^{\mathrm{a}, \mathrm{b}}$, Thierry Roisnel ${ }^{\mathrm{c}}$, Vincent Dorcet ${ }^{\mathrm{c}}$, Jean-René Hamon ${ }^{\mathrm{d}}{ }^{*}{ }^{\text {David }}$ Carrillo $^{\mathrm{a}}$, Carolina Manzur ${ }^{\mathrm{a}}$, ${ }^{*}$ Françoise Robin-Le Guen ${ }^{\mathrm{b}}$, Nolwenn Cabon ${ }^{\mathrm{b}}$ *}

a Laboratorio de Química Inorgánica, Instituto de Química, Pontificia Universidad Católica de Valparaíso, Campus Curauma, Avenida Universidad 330, Valparaíso, Chile

b UMR 6226 «Institut des Sciences Chimiques de Rennes», CNRS-Université de Rennes 1, IUT Lannion, B.P. 30219, Rue E. Branly, 22302 Lannion, France

c UMR 6226 «Institut des Sciences Chimiques de Rennes», CNRS-Université de Rennes 1, Centre de Diffractométrie X, Campus de Beaulieu, 35042 Rennes Cedex, France

d UMR 6226 «Institut des Sciences Chimiques de Rennes», CNRS-Université de Rennes 1, Campus de Beaulieu, 35042 Rennes Cedex, France

Dedicated to our distinguished colleague and friend Professor Bertrand Caro for his scientific achievements in the field of organometallic methylenepyran chemistry.

- Corresponding authors. Phone: 332232359 58, E-mail address: jean-rene.hamon@univrennes1.fr (J.-R. Hamon); Phone: 563222749 32, E-mail address: cmanzur@ucv.cl (C. Manzur); Phone: 332964694 45, E-mail address: nolwenn.cabon@univ-rennes1.fr (N. Cabon). 


\section{Abstract}

Wittig reaction between the in situ generated [2,6-diphenyl-4H-pyran-4-yl phosphorane and methyl 4-formylbenzoate afforded the methyl 4-[(2,6-diphenyl-4H-pyran-4ylidene)methyl]benzoate precursor 2 in $75 \%$ yield. The anisyl and ferrocenyl adducts of methylenepyran-containing $\beta$-diketones $\mathbf{3}$ and $\mathbf{4}$, respectively, were prepared from the basecatalyzed Claisen condensation reaction between precursor 2 and 4-methoxyacetophenone or acetylferrocene, using $t$ - $\mathrm{BuO}^{-} \mathrm{K}^{+}$as basic initiator. Both $\beta$-diketones $\mathbf{3}$ and $\mathbf{4}$ were isolated as orange and dark-red crystalline solids in 50\% yield, respectively. The acetyl derivative 6, 1acetyl-1'-methylenepyranyl-ferrocene, was synthetized following a classical Friedel-Crafts acylation reaction of the parent ferrocenylmethylenepyran $\mathbf{5}$, and isolated in $61 \%$ yield as a red microcrystalline powder. The condensation reaction between the electron-rich acetyl complex $\mathbf{6}$ and acetyl acetate, using lithium diisopropylamide as the active base initiator, provided the ferrocenylmethylenepyran-containing $\beta$-diketone, 1-(1,3-dioxobutyl)-1'-[(2,6diphenyl-4H-pyran-4-ylidene)methyl] ferrocene 7, isolated in $20 \%$ yield as an orange powder. The composition and identity of the new compounds 2-4, 6 and 7 are supported by elemental analysis, FT-IR, one- and two-dimensional ${ }^{1} \mathrm{H}$ and ${ }^{13} \mathrm{C}$ NMR spectral data and mass spectrometry. Additionally, the molecular structures of compounds 2, 4 and $\mathbf{6}$ were ascertained by single-crystal X-ray diffraction study. FT-IR and NMR spectral data indicate that both $\beta$-diketones $\mathbf{3}$ and $\mathbf{4}$ do solely exist as their keto-enol tautomeric form in solution and in the solid state, wheras a mixture of keto-enol and $\beta$-diketone tautomers in a 73:27 spectroscopic ratio was observed for $\mathbf{7}$. In the three cases, enolization takes place exclusively away from the anisyl or ferrocenyl group with formation of a six-membered pseudo-aromatic keto-enol ring, confirmed by the crystal structure of $\mathbf{4}$. Cyclic voltammetric measurements revealed that all the compounds undergo a single one-electron oxidation, localised presumably at the methylenepyran unit. This first oxidation generates a radical cation that undergoes an intermolecular $\mathrm{C}-\mathrm{C}$ bond coupling to form the corresponding dimer. Anodically shifted to the first oxidation, cyclovoltammogram of $\mathbf{4}$ exhibits one reversible two-electron oxidation while that of $\mathbf{6}$ and $\mathbf{7}$ present two successive reversible one-electron oxidations, attributed in the three cases to the ferrocenyl fragment of the dimer.

Keywords: Iron; $\beta$-diketone; methylenepyran; structure determination; ferrocene 


\section{Introduction}

Acetylacetone, also known as pentane-2,4-dione or Hacac, the quintessential example of the 1,3-dicarbonyl class of compounds $[\mathrm{RC}(\mathrm{O}) \mathrm{CHR}$ ' $\mathrm{C}(\mathrm{O}) \mathrm{R}$ ' $]$, was first prepared by Claisen about 125 years ago, from the base-catalysed condensation reaction between acetone and ethyl acetate [1]. Since that time, a number of alternative and more efficient synthetic pathways [2-5], including palladium-catalysed carbonylative $\alpha$-arylation of acetone [6], have been developed to produce a broad range of $\beta$-1,3-dicarbonyl containing organic substrates, as well as their metallocene-containing $\beta$-diketone counterparts of the type $\mathrm{Mc}-\mathrm{C}(\mathrm{O}) \mathrm{CH}_{2} \mathrm{C}(\mathrm{O}) \mathrm{R}$ $\left(\mathrm{Mc}=\left(\eta^{5}-\mathrm{C}_{5} \mathrm{H}_{5}\right) \mathrm{M}\left(\eta^{5}-\mathrm{C}_{5} \mathrm{H}_{4}\right), \mathrm{M}=\mathrm{Fe}(\mathrm{Fc}), \mathrm{Ru}(\mathrm{Rc}) ; \mathrm{R}=\mathrm{Me}, \mathrm{CF}_{3}, \mathrm{Ph}, \mathrm{Fc}, \mathrm{Rc}\right)$. Indeed, ferrocene-containing $\beta$-diketones were introduced in the late 1950s [7,8], shortly after the discovery of ferrocene [9], while its ruthenocene relatives were published only fifty years later [10]. This constant interest, over the years, of organic, inorganic and physical chemists to $\beta$-diketones and related compounds results from their valuable intrinsic chemical and physical properties. In particular, their keto-enol tautomerism has been extensively studied in solution by FT-IR and NMR spectroscopy and by electrochemistry and in the solid-state by X-ray single crystal diffraction analysis [11]. In solution, the 1,3-diketone cores generally exist as equilibrium mixtures of diketo $[\mathrm{RC}(\mathrm{O}) \mathrm{CHR}$ ' $\mathrm{C}(\mathrm{O}) \mathrm{R}$ ' $]$ and enolone $[\mathrm{RC}(\mathrm{O}) \mathrm{CR}$ ' $=\mathrm{C}(\mathrm{OH}) \mathrm{R}$ ' $]$ tautomers [10-18], whereas in the solid-state, the keto-enol isomer is generally the sole form observed [14-19]. This feature has been rationalized in terms of resonance-assisted hydrogen bond (RAHB) model based on intercorrelation between spectroscopic and crystal structure parameters, originally introduced by Gilli and co-workers [18], for explaining the abnormally strong internal hydrogen bonding within the enolone fragment. It has long been documented that $\beta$-diketones are important building blocks in organic synthesis [20-22], where in addition to their established role in the synthesis of various $\mathrm{N}$-containing heterocyclic derivatives $[23,24]$, they have been widely used for the construction of polydentate Schiff base ligands [25]. Likewise, $\beta$-diketone ligands are versatile metal coordinating agents and have played a significant role in coordination chemistry for a long time [26]. Due to the presence of two oxygen donor atoms and, as stated above, facile keto-enol tautomerism, they easily coordinate with metal ions after deprotonating the enolic hydrogen atom and provide stable metal complexes with six-membered chelate rings. Indeed, the widely used uninegative [O-CR-O $]^{-}$ chelating group is capable of stabilizing mono- and polynuclear complexes of d- [27] and fblock [28] metal ions with, for instance, applications in catalysis [29], and functional 
materials [30], and has recently gained increasing attention as constituents of polydentate ligands in metallo-supramolecular chemistry [31].

Even though less largely utilized, chalcogenomethylenepyran cores are encountered as building components in various domains including one dimensional organic conductors [32], medicinal technology [33], liquid crystals [34], nonlinear optics (NLO) [35], and molecular machine [36]. Despite the great potential of this class of molecules, organometallic chalcogenomethylenepyran compounds remain scarce. Caro and co-workers first developed and used benchrotrenyl pyrylium salts as amino acid and protein labelling reagents [37]. Those authors also opened simple and efficient routes to NLO active, unsaturated chalcogenomethylenepyran Fischer-type chromium and tungsten carbene complexes, as well as mixed sandwich iron hydrazones using pyrylium salts [38], or aldehyde functionalized methylenechalcogenopyrans [39]. Actually, $\gamma$-methylenepyrans, which are proaromatic donor, are attracting synthons as electron-donor parts in push-pull structures as they gain aromaticity upon internal charge transfer process.

In pursuit of this work, some of us were involved in the preparation of the first ferrocenylmethylenepyran derivative and have shown that its electro- or chemical oxidative coupling leads to the reversible formation of ethanediferrocenylbispyrylium salt through the dimerization of a ferrocenylmethylenepyran radical intermediate. Reversible deprotonation of ethanediferrocenylbispyrylium salt afforded an extended diferrocenylbismethylenepyran that was subsequently reversibly oxidized to ethenediferrocenylbispyrylium salt [40]. On the other hand, part of us have been interested for several years in the synthesis of functionalized ferrocenyl-containing diketones [17,41], as starting materials for the construction of push-pull unsymmetrical Schiff base complexes exhibiting NLO properties [42]. Thus, we thought that it would be of interest to design extended electron-rich ferrocenyl-containing chalcogenomethylenepyrans having a chelating coordination site, that could, upon electron and proton transfer sequences, become potential constituents of conjugated polydentate ligands.

In this piece of work, we report on the synthesis, the full analytical and spectroscopic characterization, and the electrochemical properties of a series of organic and organometallic complexes containing the methylenepyran framework bearing phenyl substituent at the 2,6 positions of the pyranyl ring, including three new $\beta$-diketones derivatives, namely, $1-\{4-[(2,6-$ diphenyl-4H-pyran-4-ylidene)methyl]phenyl \}-3-(4-methoxyphenyl)-propane-1,3-dione (3), 1- 
\{4-[(2,6-diphenyl-4H-pyran-4-ylidene)methyl]phenyl\}-3-(ferrocenyl)-propane-1,3-dione (4), and 1-(1,3-dioxobutyl)-1'-[(2,6-diphenyl-4H-pyran-4-ylidene)methyl]ferrocene (7) (see formulae in Scheme 1). In addition, the crystal and molecular structures of the ferrocenylcontaining $\beta$-diketone $\mathbf{4}$, its organic precursor $\mathbf{2}$, and of the 1-acetyl-1'-[(2,6-diphenyl-4Hpyran-4-ylidene)methyl] ferrocene derivative $\mathbf{6}$ were determined by X-ray single crystal diffraction analysis.

\section{Results and Discussion}

\subsection{Syntheses and spectroscopic characterization}

Precursor $\mathbf{2}$ is readily obtained following a Wittig-type reaction of the easily accessible 2,6diphenyl-4H-pyran-4-yl triphenylphosphonium tetrafluoroborate salt 1 [43] with methyl 4formylbenzoate. Treatment of a THF solution of the heterocyclic phosphorane, generated in situ by reaction of the phosphonium salt 1 with $n$-butyllithium, with methyl 4-formylbenzoate for 4 hours at $-75{ }^{\circ} \mathrm{C}$, afforded the 4-methylbenzoate methylenepyran 2 in $75 \%$ yield after chromatographic purification and recrystallization from dichloromethane $-n$-hexane mixture (Scheme 1). This reaction is, indeed, similar to that leading to the formation of the known ferrocenylmethylenepyran 5 [40]. Compound $\mathbf{2}$ is an air and thermally stable yellow crystalline solid with good solubility in THF, diethyl ether, dichloromethane and chloroform.

The organic and organometallic methylenepyran-containing $\beta$-diketones were prepared from the well-known base-catalyzed Claisen condensation reaction [1], at ambient temperature using potassium tert-butoxide as basic initiator [42a]. The stirring of a THF suspension of the desired salt $\left[\mathrm{R}-\mathrm{C}(=\mathrm{O}) \mathrm{CH}_{2}\right]^{-} \mathrm{K}^{+}\left(\mathrm{R}=4-\mathrm{MeO}-\mathrm{C}_{6} \mathrm{H}_{4}\right.$ or $\mathrm{Cp}-\mathrm{Fe}\left(\eta^{5}-\mathrm{C}_{5} \mathrm{H}_{4}\right)-$, in situ generated by deprotonation of 4-methoxyacetophenone or acetylferrocene with $t-\mathrm{BuO}^{-} \mathrm{K}^{+}$, in the presence of 2 equivalents of the 4-methylbenzoate methylenepyran precursor 2 for $15 \mathrm{~h}$ at room temperature, yielded the organic diketone 4-MeO- $\mathrm{C}_{6} \mathrm{H}_{4}-\mathrm{C}(=\mathrm{O}) \mathrm{CH}=\mathrm{C}(\mathrm{OH})\left(p-\mathrm{C}_{6} \mathrm{H}_{4}-\right.$ $\mathrm{CH}=$ pyran) (3), and the organometallic counterpart $\mathrm{Cp}-\mathrm{Fe}\left(\eta^{5}-\mathrm{C}_{5} \mathrm{H}_{4}\right)-\mathrm{C}(=\mathrm{O}) \mathrm{CH}=\mathrm{C}(\mathrm{OH})(p-$ $\mathrm{C}_{6} \mathrm{H}_{4}-\mathrm{CH}=$ pyran) (4), both $\beta$-diketones isolated as orange and dark-red crystalline solids, respectively, in 50\% yield after work up and recrystallization (Scheme 1).

Moreover, in order to design extended electron-rich ferrocenylmethylenepyran having a chelating 1,3-dicarbonyl coordination site, it was necessary to prepare the corresponding acetyl precursor. Ferrocene is well-known to behave as an aromatic molecule. For example, it 
can be easily acetylated with acetyl chloride in the presence of $\mathrm{AlCl}_{3}$ [44]. Therefore, ferrocenylmethylenepyran 5 was subjected to such a Friedel-Crafts acylation reaction in dichloromethane at $0^{\circ} \mathrm{C}$ for $2 \mathrm{~h}$ (Scheme 1), yielding the corresponding acetylated derivative, 1-acetyl-1'-methylenepyranyl-ferrocene $\mathbf{6}$, that was isolated in $61 \%$ yield as a red microcrystalline powder.

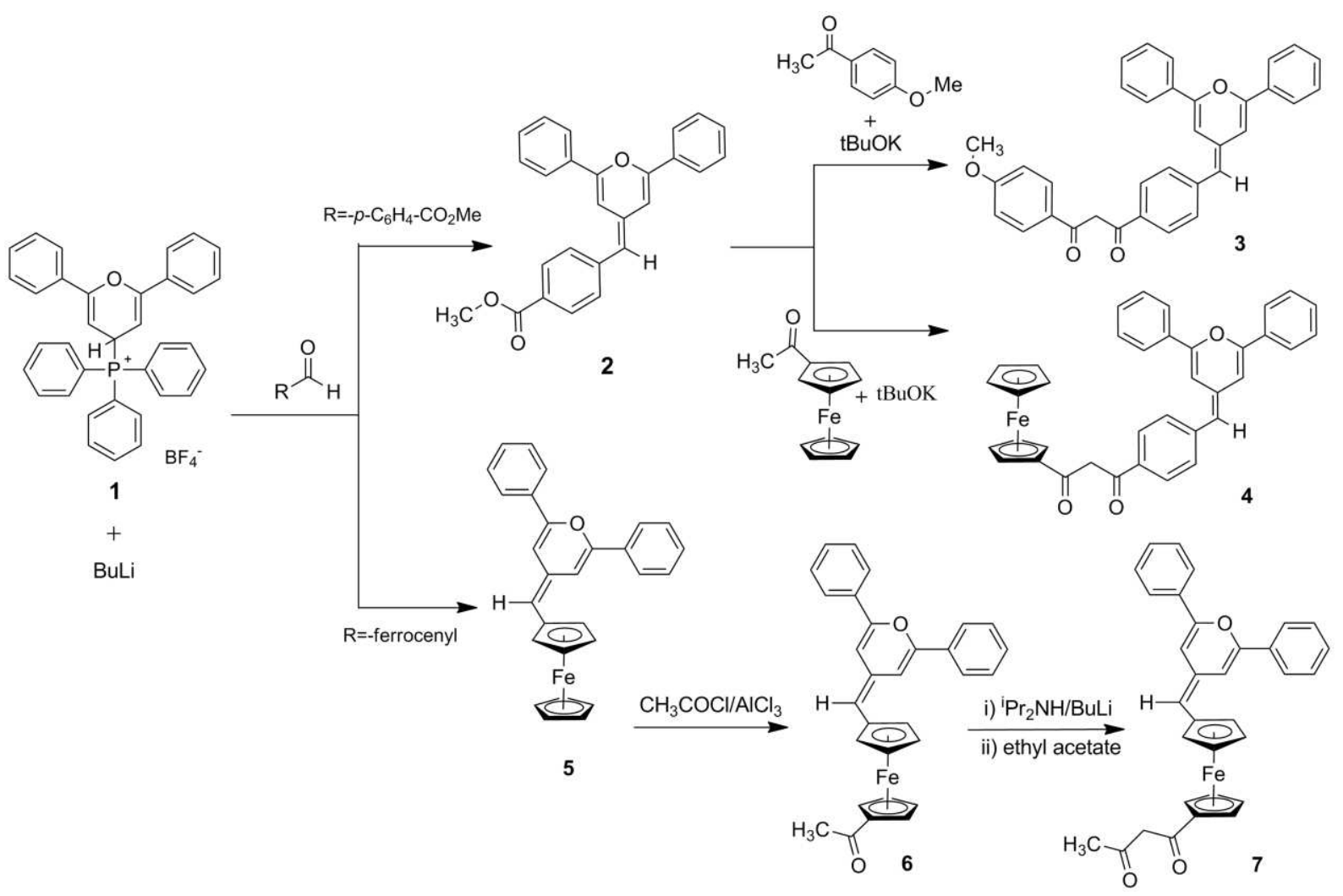

Scheme 1 Synthesis of the new compounds (2)-(4), (6) and (7).

Under the experimental conditions described above for preparing $\mathbf{3}$ and $\mathbf{4}$, the condensation reaction between the electron-rich acetyl complex $\mathbf{6}$ and acetyl acetate failed. The increased electron-donating properties of the ferrocenylmethylenepyran fragment, with respect to the ferrocenyl one, lowers the acidity of the methyl hydrogen atoms of acetyl substituent which in turn necessitates the use of a stronger base. We, therefore, used lithium diisopropylamide as the active base initiator, a route that has proven effective in the synthesis of the targeted ferrocenylmethylenepyran-containing $\beta$-diketone 7 (Scheme 1), although 7 was isolated in a modest $20 \%$ yield as an orange powder. Indeed, ${ }^{1} \mathrm{H}$ NMR analysis of the crude product showed that the $\beta$-diketone was formed in $30 \%$ spectroscopic yield, with $23 \%$ of acetyl precursor 6 , and $47 \%$ of unidentified product that could arise from self condensation of the acetyl starting material [14]. Complex 7 was separated from the reaction mixture by column 
chromatography. Use of $\mathrm{N}, \mathrm{N}$-dimethylacetamide instead of ethylacetate did not permit to improve the yield of 7 .

The new compounds, isolated as microcrystalline powders, are thermally stable air and moisture insensitive on storage under ordinary conditions, exhibiting good solubility in common polar organic solvents but are less soluble in petroleum ether and $n$-hexane and can be crystallized from them. Their composition and identity are supported by elemental analysis, FT-IR, one- and two-dimensional NMR spectral data and mass spectrometry. Additionally, the crystal and molecular structures of compounds 2, 4 and $\mathbf{6}$ were determined by single crystal X-ray diffraction analysis (see below).

The solid-state FT-IR spectra of all the new compounds exhibited medium band in the $1650-1400 \mathrm{~cm}^{-1}$ region assigned to the $v(\mathrm{C}=\mathrm{C})$ stretching mode of the methylenepyran moiety. In addition, in the spectra of $\mathbf{2}$ and $\mathbf{6}$, the ester and acetyl functionalities are identified by their intense $v(\mathrm{C}=\mathrm{O})$ stretching bands at 1715 and $1657 \mathrm{~cm}^{-1}$, respectively. The solid state FT-IR spectra of the $\beta$-diketone derivatives 3,4 and $\mathbf{7}$ are quite similar and showed $\mathrm{C}=\mathrm{O}$ and $\mathrm{C}=\mathrm{C}$ medium stretching bands at 1658-1598, 1656-1578 and 1655-1585 $\mathrm{cm}^{-1}$, respectively, in agreement with keto-enol tautomeric forms [11]. The presence of the enolone isomer is also indicated by a broad band at 3414, 3446 and $3440 \mathrm{~cm}^{-1}$, respectively, attributed to the asymmetric stretching mode of the $\mathrm{O}-\mathrm{H}$ group involved in the $[\mathrm{O}-\mathrm{H} \cdots \mathrm{O}]$ intramolecular hydrogen bond. Moreover, the spectrum of 7 presents an absorption band at $1729 \mathrm{~cm}^{-1}$ that can be assigned to the $v(\mathrm{C}=\mathrm{O})$ stretching vibration of the keto tautomeric form.

The formation of the new compounds 2-4, 6 and 7 were readily noticed in their respective ${ }^{1} \mathrm{H}$ NMR spectrum with in each case a sharp singlet at $\delta 3.87,3.91,2.36,1.93$ and $2.28 \mathrm{ppm}$ assigned to the methyl ester protons of $\mathbf{2}$, the methoxy protons of $\mathbf{3}$, and the acetyl protons of 6, 7-enol and 7-keto, respectively. For 4, the sharp peak assigned to the protons of the free cyclopentadienyl ring was found at $\delta 4.23 \mathrm{ppm}$. Additionaly, for $\mathbf{6}$ and 7, one can note that the two types of hydrogen atoms of the substituted cyclopentadienyl rings containing either the electron withdrawing acetyl or "acac" group are deshielded $(\Delta \delta 0.26$ and $0.33 \mathrm{ppm}$ for $\mathbf{6}, 0.20$ and $0.33 \mathrm{ppm}$ for 7-enol, 0.22 and $0.30 \mathrm{ppm}$ for 7-keto) compared to those attached to the cyclopentadienyl ring bearing the electron donating methylenepyran fragment.

Moreover, the ${ }^{1} \mathrm{H}$ NMR spectra of $\beta$-diketones 3 and $\mathbf{4}$, recorded at $25{ }^{\circ} \mathrm{C}$ in $\mathrm{CDCl}_{3}$, exhibited for the 1,3-dione fragment only one set of two singlets at $\delta 6.81$ and $6.41 \mathrm{ppm}$ for 
the vinylic $\mathrm{C}-\mathrm{H}$ proton, and at $\delta 17.09$ and $16.82 \mathrm{ppm}$ for the $\mathrm{O}-\mathrm{H}$ protons of the enol form, respectively. These downfield positions are in full agreement with the above discussed FT-IR data and also supported by the crystal structure of complex 4 . The above mentioned solution behaviour, where no keto tautomer can be detected, is similar to that we recently reported for $\mathrm{Cp}-\mathrm{Fe}\left(\eta^{5}-\mathrm{C}_{5} \mathrm{H}_{4}\right)-\mathrm{C}(\mathrm{O}) \mathrm{CH}=\mathrm{C}(\mathrm{OH})\left(p-\mathrm{C}_{6} \mathrm{H}_{4}-\mathrm{O}-\mathrm{C}_{5} \mathrm{H}_{9} \mathrm{O}\right)$ [17]. By contrast, the ${ }^{1} \mathrm{H}$ NMR spectrum of the $\beta$-diketone 7, also recorded at $25{ }^{\circ} \mathrm{C}$ in $\mathrm{CDCl}_{3}$, showed an enol/keto signal pair, indicating that (7) does exist as a mixture of keto-enol and $\beta$-diketone tautomers in a 73:27 spectroscopic ratio. The vinylic $\mathrm{C}-\mathrm{H}$ singlet at $\delta 5.65 \mathrm{ppm}(1 \mathrm{H})$ for the keto-enol form gave rise to a sharp resonance at $\delta 3.81 \mathrm{ppm}(2 \mathrm{H})$ for the $\beta$-diketone isomer. The downfield shifted $\mathrm{O}-\mathrm{H}$ enol proton was observed at $\delta 15.98 \mathrm{ppm}$. In the three cases, enolization takes place exclusively away from the anisyl or ferrocenyl group. This is in agreement with previous observations [13-18], and with the existence of a resonance driving force instead of an electronic driving force to explain the dominance of the $\mathrm{Cp}-\mathrm{Fe}\left(\eta^{5}-\mathrm{C}_{5} \mathrm{H}_{4}\right)-\mathrm{C}(\mathrm{O}) \mathrm{CH}=\mathrm{C}(\mathrm{OH}) \mathrm{CH}_{3}$ form toward the $\mathrm{Cp}-\mathrm{Fe}\left(\eta^{5}-\mathrm{C}_{5} \mathrm{H}_{4}\right)-\mathrm{C}(\mathrm{OH})=\mathrm{CHC}(\mathrm{O}) \mathrm{CH}_{3}$ form [14]. Indeed, a linear relationship has been established between group electronegativity $\chi_{\mathrm{R}}$ on the Gordy scale and carbonyl stretching frequency $v(\mathrm{CO})$ of methyl esters $[14,45]$. In the case of complex 2 , utilizing the carbonyl stretching frequency, one can evaluate the electronegativity of the phenyl methylenepyran $(\mathrm{R})$ fragment to be around 2.0. By extrapolation, since the electronegativity $\chi_{\mathrm{R}}$ of the ferrocenyl group is lower than that of the phenyl group on the Gordy scale, one can evaluate the ferrocenylmethylenepyran fragment to have a lower $\chi_{\mathrm{R}}$ value than the phenylmethylenepyran fragment. Consequently, from an electronic point of view and assuming the value of 2.3 for the methyl group [14,45], the dominant enol isomer should be $\mathrm{R}-\mathrm{C}(\mathrm{OH})=\mathrm{CHC}(\mathrm{O}) \mathrm{CH}_{3}$. Similarly to the ferrocenyl $\beta$-diketone [14], a resonance driving force may be taken into account to explain the observed dominant enol form for $\mathbf{7}$.

Interestingly, on passing from $\mathbf{7}$-enol to $\mathbf{4}$ and from $\mathbf{4}$ to $\mathbf{3}$, one can note two successive significant downfield shifts of $0.76 / 0.40$ and $0.84 / 0.27 \mathrm{ppm}$ for the vinylic and the enol protons, respectively, as a consequence of the participation of the pseudo-aromatic enol ring in the conjugated system, an effect that can be correlated with the increasing pyrylium character of the methylenepyran unit (see below).

The ${ }^{1} \mathrm{H}$ NMR spectra of compounds 2-4, 6 and 7 displayed also the three characteristic signal pattern attributed to the H-3, H-5 and $\mathrm{H}-7$ methine protons of the methylenepyran fragment (see Table 1 and Fig. 1 for atom labelling scheme). 
Fig. 1 Labeling scheme used for NMR assignments.

Table $1{ }^{1}$ H NMR spectral data for the methyne protons of the methylenepyran core ${ }^{a}$

\begin{tabular}{llll}
\hline Compd & $\begin{array}{l}\delta_{\mathrm{H}-3} \\
(\mathrm{ppm})\end{array}$ & $\begin{array}{l}\delta_{\mathrm{H}-5} \\
(\mathrm{ppm})\end{array}$ & $\begin{array}{l}\delta_{\mathrm{H}-7} \\
(\mathrm{ppm})\end{array}$ \\
\hline $\mathbf{2}$ & 6.64 & 7.06 & 5.96 \\
$\mathbf{3}$ & 6.46 & 7.07 & 5.97 \\
$\mathbf{4}$ & 6.49 & 7.09 & 5.98 \\
$\mathbf{6}$ & 6.34 & 6.80 & 5.46 \\
7-enol & 6.27 & 6.78 & 5.38 \\
7-keto & 6.35 & 6.79 & 5.45 \\
\hline \multicolumn{3}{r}{${ }^{a}$ recorded at $25^{\circ} \mathrm{C}$ in $\mathrm{CDCl}_{3}}$.
\end{tabular}

The ${ }^{1} \mathrm{H}$ NMR chemical shifts of the $\mathrm{H}-3 / \mathrm{H}-5$ proton have been taken as criteria for the degree of the pyrylium character [46]. In general, the chemical shifts of the hydrogen in the 3/5-position tend to shift downfield as the contribution of pyrylium resonance form increases in the ground-state structure of a compound. Thus, from comparison of the observed $\mathrm{H}-3 / \mathrm{H}-5$ chemical shift values of compounds 6 and 7 with those, more deshielded, of compounds 2-4, it apears that the ferrocenylmethylenepyran derivatives 6 and 7 have a lower pyrylium character. In 2-4 the exocyclic C-7 carbon is substituted by an electron withdrawing $p-\mathrm{C}_{6} \mathrm{H}_{4}-$ $\mathrm{C}(=\mathrm{O}) \mathrm{R}$ group whereas in $\mathbf{6}$ and $\mathbf{7}$ it bears the electron releasing ferrocenyl moiety. The electronic nature of those substituents has also a profound deshielding effect, up to $0.6 \mathrm{ppm}$, on the $\mathrm{H}-7$ proton (Table 1 ). 
The ${ }^{13} \mathrm{C}$ NMR spectra of compounds $2-4,6$ and 7 , obtained at $25{ }^{\circ} \mathrm{C}$ in $\mathrm{CDCl}_{3}$, are fully consistent with the proposed structures (see Experimental Section). For instance, the spectrum of 7 confirms the existence of the keto-enol/ $\beta$-diketone tautomeric mixture. The methyne carbon resonates at $\delta 97.6 \mathrm{ppm}$ for the keto-enol form, while it shows up at $\delta 56.6 \mathrm{ppm}$ for the $\beta$-diketone derivative. At the same time, the acetyl carbonyl carbon experiences a downfield shift from $\delta 187.1$ to $202.3 \mathrm{ppm}$, while the ferrocenoyl carbonyl carbon is slightly downfield shifted by $5.6 \mathrm{ppm}$. In addition, the ${ }^{13} \mathrm{C}$ NMR of the new compounds exhibited the five resonances expected for the five magnetically non-equivalent carbons of the methylenepyran core (see Experimental Section). For example, the spectrum of the diketone $\mathbf{3}$ showed the quaternary C-2, C-4 and C-6 carbons at $\delta 153.6,131.5$ and $151.6 \mathrm{ppm}$, respectively. The vinylic C-3 and C-5 carbons were seen at $\delta 102.0$ and $108.7 \mathrm{ppm}$, respectively, and the exocyclic C-7 carbon resonated at $\delta 113.2 \mathrm{ppm}$. Moreover, the phenyl carbons showed up as two sets of four closely spaced singlets at $\delta 124.6 / 125.0,128.6 / 128.7,129.3 / 129.6$ and 133.0/133.4 ppm for the ortho, meta, para and quaternary carbons, respectively. One can also note that the chemical shift of the C-7 carbon is sensitive to the electronic nature of its substituent, with peaks observed at $\delta 114.8,113.2$ and $113.0 \mathrm{ppm}$ in $\mathbf{2}, \mathbf{3}$ and $\mathbf{4}$, respectively, and at $\delta 109.3,108.9$ and $108.8 \mathrm{ppm}$ in 6, 7-enol and 7-keto, respectively.

\subsection{X-ray crystal structures}

The molecular structures of compounds 2, 4 and 6 with the atom labeling scheme are displayed in Figs. 2, 3 and 4, respectively, with selected bond distances and angles listed in their respective captions. The three complexes cristallize in the monoclinic centrosymmetric space group $P 2_{1} / n$. Two crystallographically independent molecules $(\mathbf{2 A}$ and $\mathbf{2 B})$ are found in the asymmetric unit cell of $\mathbf{2}$ while that of $\mathbf{4}$ and $\mathbf{6}$ contains each a single molecule. The single-crystal X-ray diffraction studies confirm both the monomeric nature and that each compound consists of a [(2,6-diphenyl-4H-pyran-4-ylidene)methyl] group linked to an aromatic $\mathrm{C}_{6}$-ring in the case of the $\beta$-diketone $\mathbf{4}$ and of its precursor $\mathbf{2}$, and to an acetylferrocene moiety in the case of $\mathbf{6}$. Whatever the substituent at the exocyclic methine carbon atom, the methylenepyran cores remain structurally very similar with alternating single and double C-C bonds. Table S1 (see Supplementary material) compares their bond distances and angles, that are in accordance with previously reported structural data [40]. The exocyclic C-C bond lengths lie in the range 1.353(10) - 1.370(10) $\AA$, thus suggesting a weak pyrylium character [40]. In addition, the mean planes of the aromatic rings at C-2, C-6 and C- 
7 (this atom labelling refers to Fig. 1) are tilted with respect to the mean plane of the methylenepyran core with dihedral angles of $6.77,19.37$ and $34.65^{\circ}$ for $\mathbf{2 A}, 6.22,19.56$ and $34.85^{\circ}$ for $\mathbf{2 B}, 3.75,14.81$ and $18.23^{\circ}$ for $\mathbf{4}$, and $17.60,14.12$ and $30.28^{\circ}$ for $\mathbf{6}$, respectively.

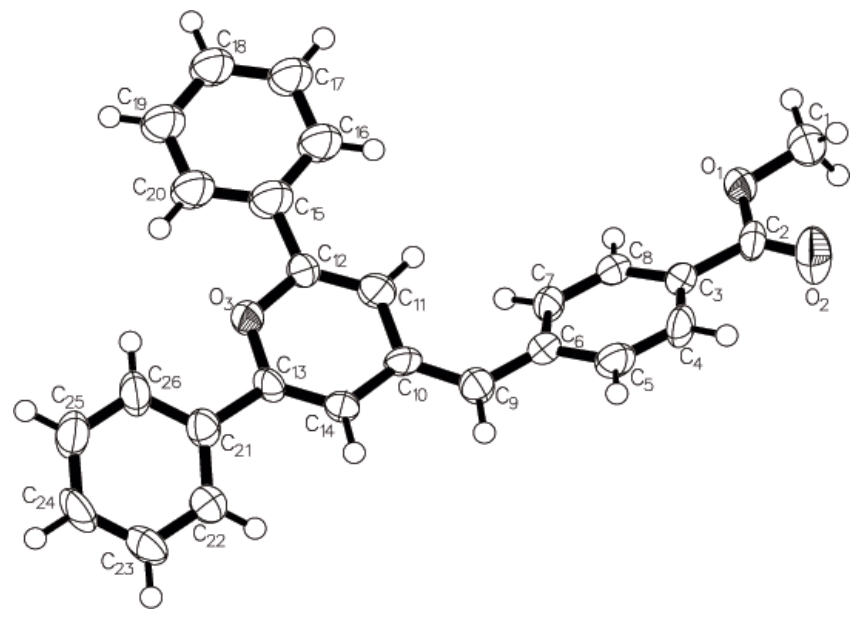

Fig. 2 Molecular structure of $\mathbf{2}$ with the atom numbering scheme; only molecule $\mathbf{2 A}$ is shown. Hydrogen atoms have been omitted for clarity. Thermal ellipsoids are drawn at 50\% probability. Selected bond distances $[\AA ̊ \AA]$ and angles $\left[{ }^{\circ}\right]$ : $\mathrm{O}(1)-\mathrm{C}(1)$ 1.436(8), O(1)-C(2) 1.348 (9), $\mathrm{O}(2)-\mathrm{C}(2)$ 1. 197(9), $\mathrm{C}(9)-\mathrm{C}(10)$ 1.370(10), $\mathrm{C}(11)-\mathrm{C}(12)$ 1.338(10), $\mathrm{C}(13)-\mathrm{C}(14)$ 1.336(9), O(3)-C(12) 1.377(8), O(3)-C(13) 1.376(8); C(1)-O(1)-C(2) 115.1(6), O(1)-C(2)$\mathrm{O}(2) \quad 123.8(7), \quad \mathrm{O}(2)-\mathrm{C}(2)-\mathrm{C}(3) \quad 124.4(8), \quad \mathrm{C}(6)-\mathrm{C}(9)-\mathrm{C}(10) \quad 127.8(7), \quad \mathrm{C}(9)-\mathrm{C}(10)-\mathrm{C}(11)$ 126.8(7), $\quad \mathrm{C}(9)-\mathrm{C}(10)-\mathrm{C}(14) \quad 120.1(7), \quad \mathrm{C}(10)-\mathrm{C}(11)-\mathrm{C}(12) \quad 122.7(7), \quad \mathrm{C}(10)-\mathrm{C}(14)-\mathrm{C}(13)$ 121.7(7), $\quad \mathrm{O}(3)-\mathrm{C}(12)-\mathrm{C}(11) \quad 121.4(7), \quad \mathrm{O}(3)-\mathrm{C}(13)-\mathrm{C}(14) \quad 122.9(6), \quad \mathrm{O}(3)-\mathrm{C}(12)-\mathrm{C}(15)$ 111.9(6), O(3)-C(13)-C(21) 111.2(6), C(12)-O(3)-C(13) 118.0(6).

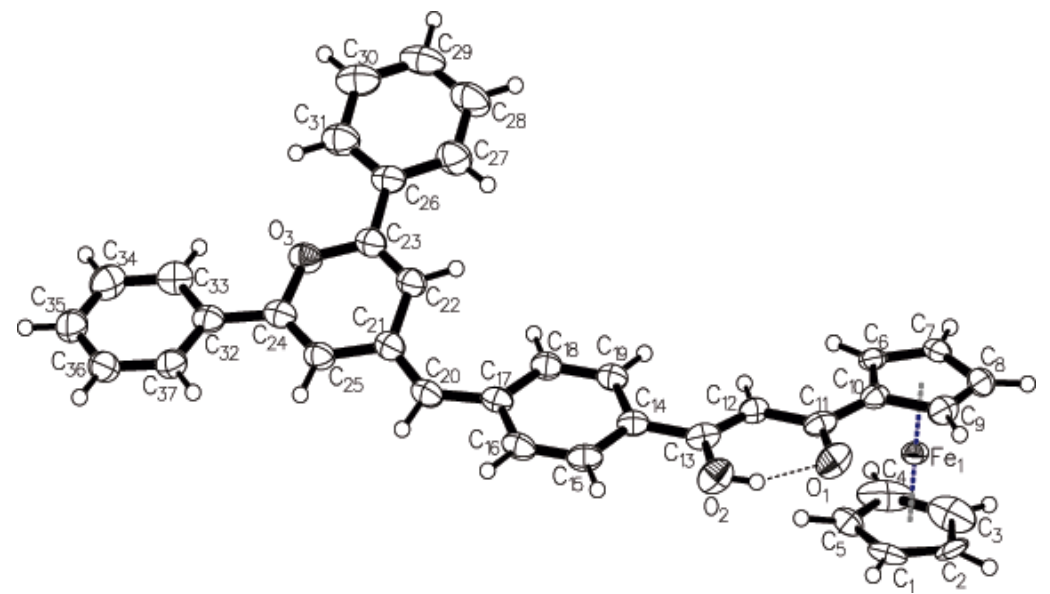

Fig. 3 Molecular structure of $\mathbf{4}$ with the atom numbering scheme. Hydrogen atoms have been omitted for clarity. Thermal ellipsoids are drawn at $50 \%$ probability. Selected bond distances 


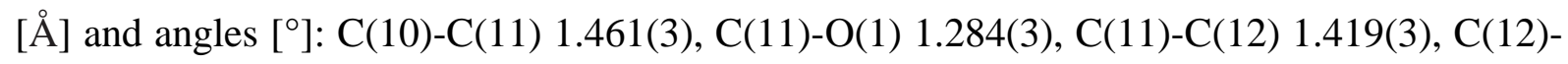
$\mathrm{C}(13)$ 1.381(3), $\mathrm{C}(13)-\mathrm{O}(2)$ 1.313(3), $\mathrm{C}(13)-\mathrm{C}(14)$ 1.466(3), C(20)-C(21) 1.360(3), $\mathrm{C}(22)-$ $\mathrm{C}(23)$ 1.334(3), $\mathrm{C}(23)-\mathrm{O}(3)$ 1.374(3), $\mathrm{C}(24)-\mathrm{O}(3)$ 1.382(3), $\mathrm{C}(24)-\mathrm{C}(25)$ 1.340(3); $\mathrm{O}(1)-$ $\mathrm{C}(11)-\mathrm{C}(10)$ 118.0(2), O(1)-C(11)-C(12) 120.7(2), C(11)-C(12)-C(13) 120.1(2), O(2)-C(13)$\mathrm{C}(12)$ 120.3(2), O(2)-C(13)-C(14) 115.6(2), C(17)-C(20)-C(21) 132.8(2), C(20)-C(21)-C(22) 127.7(2), $\mathrm{C}(20)-\mathrm{C}(21)-\mathrm{C}(25) \quad 120.0(2), \quad \mathrm{C}(21)-\mathrm{C}(22)-\mathrm{C}(23) \quad 122.4(2), \quad \mathrm{C}(21)-\mathrm{C}(25)-\mathrm{C}(24)$ 123.6(2), $\quad \mathrm{O}(3)-\mathrm{C}(23)-\mathrm{C}(22) \quad 122.0(2), \quad \mathrm{O}(3)-\mathrm{C}(24)-\mathrm{C}(25) \quad 120.7(2), \quad \mathrm{O}(3)-\mathrm{C}(23)-\mathrm{C}(26)$ 111.0(2), O(3)-C(24)-C(32) 111.6(2), C(23)-O(3)-C(24) 118.56(19).

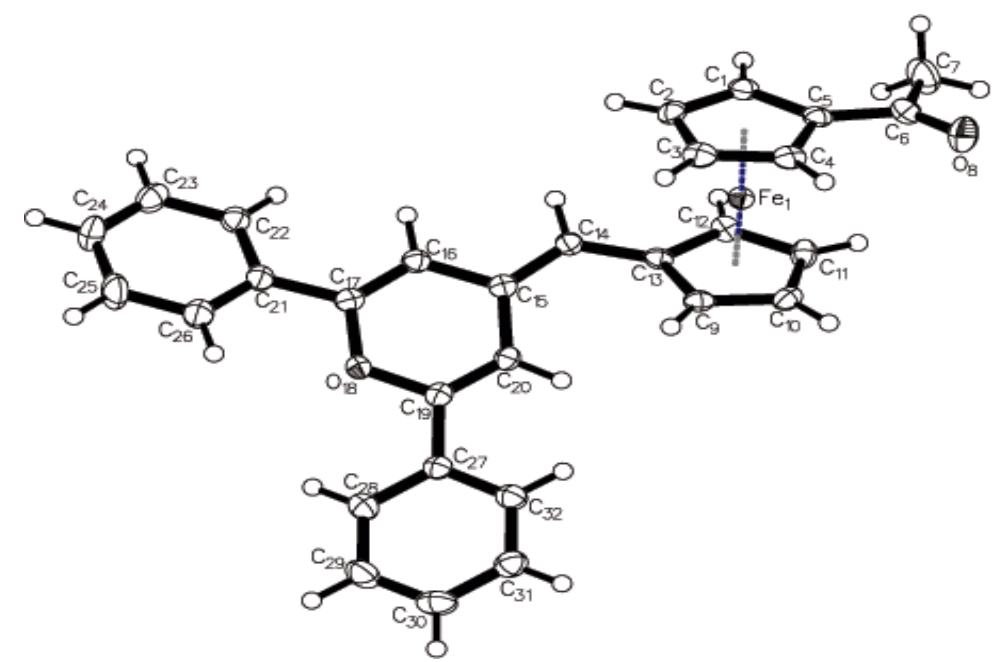

Fig. 4 Molecular structure of $\mathbf{6}$ with the atom numbering scheme. Hydrogen atoms have been omitted for clarity. Thermal ellipsoids are drawn at 50\% probability. Selected bond distances $[\AA]$ and angles [ ${ }^{\circ}$ ]: $\mathrm{C}(5)-\mathrm{C}(6) 1.477(3), \mathrm{C}(6)-\mathrm{O}(8)$ 1.219(3), $\mathrm{C}(6)-\mathrm{C}(7)$ 1.506(4), $\mathrm{C}(14)-\mathrm{C}(15)$ 1.357(3), C(16)-C(17) 1.335(3), C(19)-C(20) 1.335(3), O(18)-C(17) 1.389(3), O(18)-C(19) 1.385(3); $\mathrm{O}(8)-\mathrm{C}(6)-\mathrm{C}(5)$ 121.1(2), $\mathrm{O}(8)-\mathrm{C}(6)-\mathrm{C}(7)$ 121.2(2), C(13)-C(14)-C(15) 127.8(2), $\mathrm{C}(14)-\mathrm{C}(15)-\mathrm{C}(16)$ 120.8(2), $\mathrm{C}(14)-\mathrm{C}(15)-\mathrm{C}(20)$ 126.5(2), $\mathrm{C}(15)-\mathrm{C}(16)-\mathrm{C}(17) \quad 122.8(2)$, $\mathrm{C}(15)-\mathrm{C}(20)-\mathrm{C}(19)$ 122.4(2), O(18)-C(17)-C(16) 121.57(19), O(18)-C(19)-C(20) 122.26(19), $\mathrm{O}(18)-\mathrm{C}(17)-\mathrm{C}(21) \quad 111.72(19), \quad \mathrm{O}(18)-\mathrm{C}(19)-\mathrm{C} 27) \quad 111.41(19), \quad \mathrm{C}(17)-\mathrm{O}(18)-\mathrm{C}(19)$ 118.04(17).

Complexes 4 and 6 contain the 1-ferrocenyl and 1,1'-ferrocenyl moiety, respectively. In compound 4 , the iron atom is coordinated to the free and substituted cyclopentadienyl rings at ring centroid-iron distances of 1.661 and $1.642 \AA$, respectively, whereas in compound 6 the two ring centroid-iron distances are identical and equal to $1.650 \AA$, although one ring bears a donor methylenepyran substituent and the other an acceptor acetyl one. In each 
organometallic fragment, the two carbocyclic ligands are essentially parallel with ring centroid-iron-ring centroid angles of $177.5^{\circ}$ for $\mathbf{4}$ and $177.6^{\circ}$ for $\mathbf{6}$. Those metrical parameters clearly feature a linear sandwich structures with typical $\left[\eta^{5}-\mathrm{Fe}-\eta^{5}\right]$ coordination mode, and indicate that there is a $\mathrm{Fe}(\mathrm{II})$ oxidation state in each metallocene [47].

On the other hand, within both 4 and 6 the acyl units $\mathrm{C}(10)-\mathrm{C}(11)-\mathrm{O}(1)$ and $\mathrm{C}(5)-\mathrm{C}(6)-\mathrm{O}(8)$ are almost coplanar with their corresponding attached cyclopentadienyl rings $\mathrm{C}(6){ }^{\cdots} \mathrm{C}(10)$ and $\mathrm{C}(1)^{\cdots} \mathrm{C}(5)$ with dihedral angles of 5.42 and $7.66^{\circ}$, respectively. This is typical of the conformations observed in acyl ferrocenes Fc-COR [41,48]. Additionally, in complex 6, the acetyl group exhibits a classical $\mathrm{O}(1)-\mathrm{C}(6)-\mathrm{C}(7)$ angle of $121.2(2)^{\circ}[41,48]$, and in the two complexes, the $\mathrm{C}-\mathrm{C}$ and $\mathrm{C}-\mathrm{Fe}$ bond distances of the ferrocene sandwiches as well as the $\mathrm{C}=\mathrm{O}$ bond distance fall all within the range of standard values [49].

In compound 4 , the angles at $\mathrm{C}(11), \mathrm{C}(12)$ and $\mathrm{C}(13)$ of the $[\mathrm{O}(1)-\mathrm{C}(11)-\mathrm{C}(12)-\mathrm{C}(13)-\mathrm{O}(2)]$ central core are of 120.7(2), 120.1(2) and 120.3(2) ${ }^{\circ}$, respectively, that are idealized value expected for a $\mathrm{sp}^{2}$-hybridized carbon atom. The $\mathrm{O}(1)-\mathrm{C}(11), \mathrm{C}(11)-\mathrm{C}(12), \mathrm{C}(12)-\mathrm{C}(13)$ and $\mathrm{C}(13)-\mathrm{O}(2)$ bond lengths (see caption of Fig. 3) observed in this planar skeleton correspond to alternating double-, single-, double- and single-bonds [49], exhibiting partial delocalization of the $\mathrm{O}=\mathrm{C}-\mathrm{C}=\mathrm{C}-\mathrm{O}$ system. Those metrical parameters are consistent with a keto-enol tautomeric form for 4, with an intramolecular $\mathrm{O}(1)^{\cdots} \mathrm{H}-\mathrm{O}(2)$ hydrogen bonding interaction which closes a six-membered pseudo-aromatic ring through the resonant $\cdots \mathrm{O}=\mathrm{C}-\mathrm{C}=\mathrm{C}-\mathrm{OH} \cdots$ fragment [18]. The $\mathrm{O} \cdots \mathrm{O}$ separation is equal to $2.450 \AA$, in accordance with previously reported values for keto-enol tautomers of $\beta$-diketone derivatives [13-19]. In addition, the plane of the [OCCCO] framework is almost coplanar with both the substituted cyclopentadienyl ring and the phenylene ring, making dihedral angles of 6.22 and $7.02^{\circ}$, respectively, a situation that should allow partial conjugation between the two parts of the molecule. Lastly, the crystal packing of (4) is effected by intermolecular interactions between an hydrogen atom and the carbonyl oxygen atom $\left(\mathrm{C}(6)-\mathrm{H}(6)^{\cdots} \mathrm{O}(1)=3.454 \AA, \mathrm{H}(6){ }^{\cdots} \mathrm{O}(1)=\right.$ $2.666 \AA$ and $\mathrm{C}(6)-\mathrm{H}(6)^{\cdots} \mathrm{O}(1)=140.8^{\circ}$; symmetry code: 1-x, 1-y,-z ) (Supplementary material, Fig. S1).

\section{2-3-Electrochemical studies}

The redox behavior of these new organic and organometallic compounds 2-4, 6 and 7 was investigated by cyclic voltametry in dichloromethane containing $0.1 \mathrm{M} n-\mathrm{Bu}_{4} \mathrm{~N}^{+} \mathrm{BF}_{4}^{-}$as 
supporting electrolyte (see Figure 5, and Figures S2-S4 of the Supplementary material). Their electrochemical data together with those of the known ferrocenylmethylenepyran 5 [40a], and phenylmethylenepyran ( $\mathrm{Ph}-\mathrm{CH}=$ pyran) 8 [40c], are gathered in table 2.

For all of the compounds, an irreversible anodic wave, classically observed for methylenepyran derivatives [40], was observed between -0.05 and $0.34 \mathrm{~V} v s$ ferrocene/ferricenium $\left(\mathrm{Cp}_{2} \mathrm{Fe}^{+/ 0}\right)$ redox couple (Table 2). For (2)-(4), values of the oxidation potential $(0.23-0.34 \mathrm{~V})$ are comparable to that measured for the parent phenylmethylenepyran compound $8(0.23 \mathrm{~V})$ [40c]. For the organometallic derivatives 6 and 7, only slight variation of the oxidation potential was observed when compared to that of the parent ferrocenylmethylenepyran derivative $\mathbf{5}$, since the oxidation potential of this compound was observed at $-0.15 \mathrm{~V}$ [40b]. According to the DFT calculations carried out for $\mathbf{5}$, which shows that the three highest occupied MOs have a large metal contribution [40c], the main difference between $2,3,4,8$ and $5,6,7$ may originate from the nature of the oxidized site that seems to be the pyran and the ferrocenyl units, respectively.

Table 2 Electrochemical data for compounds $\mathbf{2 - \mathbf { 8 } ^ { a }}$

\begin{tabular}{lllll}
\hline Compd & $E_{\text {ox }}(1)^{b}$ & $E_{\text {red }}{ }^{c}$ & $E_{1 / 2}(2)$ & $E_{1 / 2}(3)$ \\
\hline $\mathbf{2}$ & 0.34 & -0.82 & & \\
$\mathbf{3}$ & 0.32 & -0.82 & & \\
$\mathbf{4}$ & 0.23 & -0.86 & $0.25\left(2 \mathrm{e}^{-}\right)$ & \\
$\mathbf{5}^{d}$ & -0.15 & -0.76 & 0.12 & 0.28 \\
$\mathbf{6}$ & -0.02 & -0.83 & 0.37 & 0.47 \\
$\mathbf{7}$ & -0.05 & -0.77 & 0.33 & 0.44 \\
$\mathbf{8}^{d}$ & 0.23 & -0.86 & & \\
\hline
\end{tabular}

${ }^{a}$ recorded in $\mathrm{CH}_{2} \mathrm{Cl}_{2} / 0.1 \mathrm{M} n-\mathrm{Bu}_{4} \mathrm{~N}^{+} \mathrm{BF}_{4}^{-}$at $0.1 \mathrm{~V} \mathrm{~s}^{-1}$, at $298 \mathrm{~K}$; redox potentials quoted in $\mathrm{V}$ vs. the ferrocene/ferricenium couple $\left(\mathrm{Cp}_{2} \mathrm{Fe}^{+/ 0}\right) .{ }^{b}$ Irreversible peak. ${ }^{c}$ Irreversible peak on the reverse cathodic scan. ${ }^{d}$ Data from Ref. [40].

Moreover, on the reverse scan of the cyclic voltamogramm, a new irreversible cathodic wave was observed between -0.69 and $-0.86 \mathrm{~V} v s \mathrm{Cp}_{2} \mathrm{Fe}^{+/ 0}$ that is not observed when the scan is directly run in reduction (Fig. 5). This electrochemical behaviour is consistent with monoelectronic oxidation followed by rapid dimerization, as previously demonstrated for ferrocenylmethylenepyran compounds [40a,b]. Indeed, the first oxidation generates a radical cation which undergoes an intermolecular $\mathrm{C}-\mathrm{C}$ bond coupling to form a dimer. The latter is 
detected on the back scan with the observation of an irreversible reduction wave. Finally, when the scan direction was reversed toward more positive potentials, after the appearance of the reduction wave, the voltamogram was identical to the one obtained in the initial scan. This observation suggests that the product formed upon oxidation is reduced back to the original compound. This kind of behaviour, already observed by us [40], has also been observed in other molecular systems [50], and suggests that $\mathrm{C}-\mathrm{C}$ bond making/breaking is reversibly induced upon electron transfer.

Finally, for the ferrocenyl-containing compounds, two successive reversible one-electron oxidation waves for $\mathbf{6}$ and $\mathbf{7}$ and one reversible two-electron oxidation for $\mathbf{4}$ (based on current ratio) were observed following the first oxidation process. Cyclic voltammograms of $\mathbf{4}$ and $\mathbf{7}$ are displayed in fig. 5, whereas that of $\mathbf{6}$ is presented in Fig. S4 (Supplementary material). Compared to the precursor compound $\mathbf{5}$, a positive shift is observed for $\mathbf{6}$ and $\mathbf{7}$, due to the presence of the electron withdrawing substituent. As previously shown for the ferrocenylmethylenepyran $\mathbf{5}$, these oxidation waves may be assigned to the ferrocenyl groups of the dicationic dimer formed after the first oxidation. In the particular case of $\mathbf{4}$, this behaviour suggests that there is no electronic communication between the two ferrocenyl fragments [51].
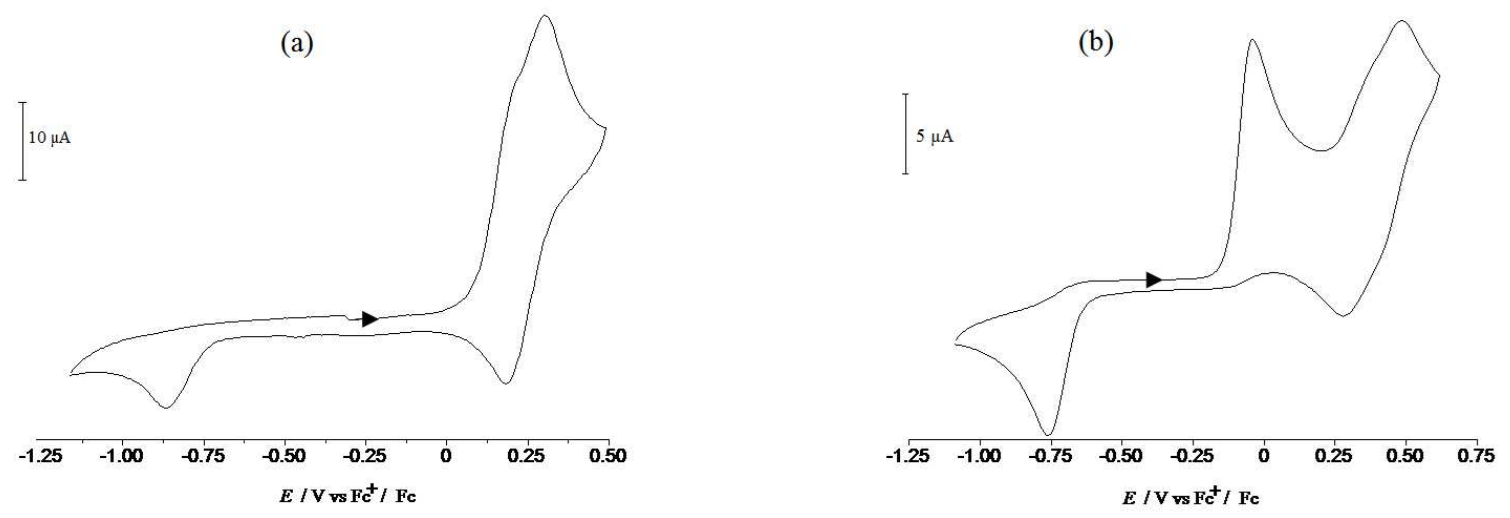

Fig. 5 Cyclic voltammograms of compounds 4 (a) and 7 (b) at a Pt disk working electrode, in $\mathrm{CH}_{2} \mathrm{Cl}_{2} / 0.1 \mathrm{M}\left[n-\mathrm{Bu}_{4} \mathrm{~N}\right]\left[\mathrm{BF}_{4}\right]$ at $298 \mathrm{~K}$. Redox potentials are quoted vs. the ferrocene/ferricenium couple $\left(\mathrm{Cp}_{2} \mathrm{Fe}^{+/ 0}\right)$. 


\section{Conclusions}

In this contribution, a new family of electron-rich methylenepyran derivatives has been successfully synthesized and fully characterized, and their redox properties thoroughly investigated. All the compounds described in this work contain the 4-[(2,6-diphenyl-4Hpyran-4-ylidene)methyl] fragment substituted at the exocyclic $\mathrm{CH}=\mathrm{C}$ carbon by either $p$ $\mathrm{C}_{6} \mathrm{H}_{4} \mathrm{CO}_{2} \mathrm{CH}_{3}$ (2), $p-\mathrm{CH}_{3} \mathrm{OC}_{6} \mathrm{H}_{4}-\mathrm{COCH}_{2} \mathrm{CO}-p-\mathrm{C}_{6} \mathrm{H}_{4}(3), \mathrm{CpFe}\left(\mathrm{C}_{5} \mathrm{H}_{4}\right)-\mathrm{COCH}_{2} \mathrm{CO}-p-\mathrm{C}_{6} \mathrm{H}_{4}$ (4), $\left(\mathrm{CH}_{3} \mathrm{COC}_{5} \mathrm{H}_{4}\right) \mathrm{Fe}\left(\mathrm{C}_{5} \mathrm{H}_{4}\right)(\mathbf{6})$, and $\left(\mathrm{CH}_{3} \mathrm{COCH}_{2} \mathrm{COC}_{5} \mathrm{H}_{4}\right) \mathrm{Fe}\left(\mathrm{C}_{5} \mathrm{H}_{4}\right)$ (7). Compounds 2,4 and 6 were also authenticated by single-crystal X-ray diffraction analysis. FT-IR and 1D and 2D NMR studies clearly show that both $\beta$-diketones $\mathbf{3}$ and $\mathbf{4}$ do exist solely as their keto-enol tautomeric form in solution, wheras a mixture of keto-enol and $\beta$-diketone tautomers was observed for $\mathbf{7}$ in a 73:27 spectroscopic ratio. Enolization takes place exclusively away from the anisyl or ferrocenyl group, suggesting the existence of a resonance driving force instead of an electronic driving force to explain the dominance of the $\mathrm{R}-\mathrm{C}(\mathrm{O}) \mathrm{CH}=\mathrm{C}(\mathrm{OH})$ - form $(\mathrm{R}=$ anisyl, Fc). This is supported by the crystal structure of complex $\mathbf{4}$, where the six-membered pseudo-aromatic keto-enol ring is coplanar with the cyclopentadienyl and phenylene ring substituents, thus allowing a partial conjugation between the two redox active parts of the molecule. Owing to their electron-rich nature, the methylenepyran compounds 2-4, 6 and 7, studied by cyclic voltammetry are readily oxidized to radical cations. The oxidation potential values are markedly affected by the position of the ferrocenyl ring toward the methylenepyrane fragment. The unstable radical cation evolves by dimerization in bispyrylium systems that regenerate the starting material upon reduction. These systems, undergoing reversible $\mathrm{C}-\mathrm{C}$ bond making/breaking upon electron transfer, might be interesting in the construction of molecular switches or memories based on their electrochemical response. On the other hand, the new unsymmetrical electron-rich methylenepyran-containing 1,3-diketones $\mathbf{3}, \mathbf{4}$ and $\mathbf{7}$ are also expected to be strong chelating agents toward transition metal ions, and may also serve as valuable building blocks in the construction of polydentate Schiff base ligands, as well as in the synthesis of heterocyclic compounds such as pyrazoles which are known to have a broad spectrum of biological activities. 


\section{Experimental Section}

\subsection{General Experimental Methods}

Manipulations of air-sensitive compounds were performed under a dry dinitrogen atmosphere using standard Schlenk techniques. Solvents were dried and distilled under dinitrogen by standard methods prior to use. ${ }^{[52]}$ Chromatographic purification was performed with Silicagel $60(0.063-0.200 \mu \mathrm{m})$. 2,6-diphenyl-4H-pyran-4-yl triphenylphosphonium tetrafluoroborate $\mathbf{1},{ }^{[43]}$ ferrocenylmethylenepyran $\mathbf{5},{ }^{[40]}$ and phenylmethylenepyran $\mathbf{8},{ }^{[53]}$ were synthesized according to published procedures. Methyl 4-formylbenzoate, $n$-butyllithium $(2.5 \mathrm{M}$ in hexanes), acetylferrocene, potassium tert-butoxide, 4-methoxyacetophenone, diisopropylamine and petroleum ether 40-60 were purchased from Aldrich and used as received. Solid-state FT-IR spectra were recorded on a Perkin Elmer model 1600 FT-IR or 1000 FTIR spectrophotometer using $\mathrm{KBr}$ disks, in the range 4000-450 $\mathrm{cm}^{-1} \cdot{ }^{1} \mathrm{H}$ and ${ }^{13} \mathrm{C}$ NMR spectra were recorded with either a Bruker Avance III 400 spectrometer at the Universidad Federico Santa María (Valparaíso, Chile), or a Bruker AV 500 at the Centre Régional de Mesures Physiques de 1'Ouest (CRMPO, Rennes, France) or a Bruker DRX 500 spectrometer at the Service Commun de Recherche de Résonance Magnétique Nucléaire et de Résonance Paramagnétique Electronique de l'Université de Bretagne Occidentale (Brest, France). Chemical shifts $(\delta)$ are reported in parts per million (ppm) and referenced to the residual deuterated solvent peaks. Coupling constants $(J)$ are reported in Hertz $(\mathrm{Hz})$, and integrations are reported as number of protons. The following abbreviations are used to describe peak patterns: br $=$ broad, $\mathrm{s}=$ singlet, $\mathrm{d}=$ doublet, $\mathrm{t}=$ triplet, $\mathrm{m}=$ multiplet. ${ }^{1} \mathrm{H}$ and ${ }^{13} \mathrm{C} \mathrm{NMR}$ chemical shift assignments are supported by using COSY, HMQC and HMBC NMR techniques, and are given according to the numbering scheme of Figure 1. High resolution electro spray ionization mass spectra (ESI-MS) were obtained at the CRMPO (Rennes) with a WATERS Q-TOF spectrometer. Elemental analyses were conducted on a ThermoFINNIGAN Flash EA 1112 CHNS/O analyzer by the Microanalytical Service of the CRMPO (Rennes). Cyclic voltammetry experiments were performed with a $\mu$-AUTOLAB III potentiostat monitored by a computer. A three-electrode cell was used, equipped with a platinum wire auxiliary electrode, a glassy carbon or a platinum working electrode, $\mathrm{Ag} / \mathrm{AgCl}$ non aqueous as reference or silver wire as a quasi-reference electrode. All the potential are quoted against the ferrocene-ferricenium redox couple; ferrocene was added as an internal standard at the end of each experiment [54]. Melting points were measured in evacuated capillaries on a Kofler Bristoline melting point apparatus and are uncorrected. 


\subsection{Synthesis of methyl 4-[(2,6-diphenyl-4H-pyran-4-ylidene)methyl]benzoate (2)}

To a Schlenk tube containing a stirred solution of 2,6-diphenyl-4H-pyran-4-yl triphenylphosphonium tetrafluoroborate salt $\mathbf{1}(2.90 \mathrm{~g}, 4.98 \mathrm{mmol})$ in THF $(40 \mathrm{~mL})$, cooled to $-75^{\circ} \mathrm{C}$, was added dropwise $n$-butyllithium $(2.30 \mathrm{~mL}, 5.78 \mathrm{mmol})$. The solution turned black. After $15 \mathrm{~min}$ of stirring, solid methyl 4-formylbenzoate (0.818 g, $4.98 \mathrm{mmol})$ was slowly added. The reaction mixture was stirred at $-75{ }^{\circ} \mathrm{C}$ for $4 \mathrm{~h}$. Then, the solvent was evaporated under reduced pressure at room temperature (r.t.). The solid residue was dissolved in a minimum amount of dichloromethane (DCM) and absorbed on a column packed with silica gel (grade 60). Elution with petroleum ether-DCM mixture (1:1) produced the release of a yellow band that was collected. The solvent was evaporated under reduced pressure and the product was recrystallized from DCM-hexane mixture (1:1), affording yellow microcrystals of 2 (1.40 g, 75\% yield). A crystal from this crop was used for X-ray structure determination. M.p. $130-132{ }^{\circ} \mathrm{C} . \mathrm{C}_{26} \mathrm{H}_{20} \mathrm{O}_{3} \bullet 0.05 \mathrm{CH}_{2} \mathrm{Cl}_{2}\left(384.2 \mathrm{~g} \mathrm{~mol}^{-1}\right)$ : Calcd. C 81.36, $\mathrm{H}$ 5.21; found C 81.42, H 5.23. IR $\left(\mathrm{KBr}, \mathrm{cm}^{-1}\right): 1715(\mathrm{~s})(\mathrm{C}=\mathrm{O}), 1656(\mathrm{~m})(\mathrm{C}=\mathrm{C}), 1595,1581$, 1493, 1447, (C=C), $1270(\mathrm{O}-\mathrm{C}) .{ }^{1} \mathrm{H}$ NMR (400 MHz, $\left.\mathrm{CD}_{3} \mathrm{COCD}_{3}, 25^{\circ} \mathrm{C}\right): \delta 3.75(\mathrm{~s}, 3 \mathrm{H}$, $\left.\mathrm{CH}_{3}\right), 5.96(\mathrm{~s}, 1 \mathrm{H}, \mathrm{H}-7), 6.64\left(\mathrm{~d},{ }^{4} J_{\mathrm{H}, \mathrm{H}}=1.75 \mathrm{~Hz}, 1 \mathrm{H}, \mathrm{H}-3\right), 7.06\left(\mathrm{~d},{ }^{4} J_{\mathrm{H}, \mathrm{H}}=1.75 \mathrm{~Hz}, 1 \mathrm{H}, \mathrm{H}-\right.$ 5), 7.38 (m, $6 \mathrm{H}, \mathrm{H}-23,24,25$ and H-63,64,65), 7.44 (d, $\left.{ }^{3} J_{\mathrm{H}, \mathrm{H}}=7.8 \mathrm{~Hz}, 2 \mathrm{H}, \mathrm{H}-9,13\right), 7.79$ (t, ${ }^{3} J_{\mathrm{H}, \mathrm{H}}=6.8 \mathrm{~Hz}, 4 \mathrm{H},-\mathrm{H} 22,26$ and H-62,66), $7.85\left(\mathrm{~d},{ }^{3} J_{\mathrm{H}, \mathrm{H}}=7.8 \mathrm{~Hz}, 2 \mathrm{H}, \mathrm{H}-10,12\right) .{ }^{13} \mathrm{C} \mathrm{NMR}$ $\left(100 \mathrm{MHz}, \mathrm{CD}_{3} \mathrm{COCD}_{3}, 25^{\circ} \mathrm{C}\right): \delta 52.5\left(\mathrm{CH}_{3}\right), 102.9(\mathrm{C}-3), 109.9(\mathrm{C}-5), 114.8(\mathrm{C}-7), 125.8$, 126.3, 127.9, 128.8, 130.0, 130.1, 130.6, 130.9 (C-H arom), 131.0, 132.5, 134.2, 134.3 ( $\left.\mathrm{C}_{\text {quat }}\right)$, 144.7 (C-11), 152.5 (C-6), 154.8 (C-2), $167.5(\mathrm{C}=\mathrm{O})$.

4.3. Synthesis of 1-\{4-[(2,6-diphenyl-4H-pyran-4-ylidene)methyl]phenyl\}-3-(4methoxyphenyl) propane-1,3-dione (3)

A Schlenk tube was charged with a magnetic stir bar, 4-methoxyacetophenone $(0.220 \mathrm{~g}, 1.46$ mmol), potassium tert-butoxide $(0.250 \mathrm{~g}, 2.23 \mathrm{mmol})$ and $3.0 \mathrm{~mL}$ of THF. The reaction mixture was vigourously stirred for $15 \mathrm{~min}$ before a solid sample of compound 2 (1.10 g, 2.89 mmol) was slowly added. After $10 \mathrm{~min}$ of stirring, $2.0 \mathrm{~mL}$ of THF were additionally added and the vigorous stirring was continued for $15 \mathrm{~h}$ at r.t. The reaction was quenched with water and partitioned between water and DCM (3 x $50 \mathrm{~mL})$. The combined organic extracts were dried over $\mathrm{MgSO}_{4}$, concentrated and adsorbed on a column packed with silica gel. Elution with petroleum ether-DCM mixture (2:8) produced the release of an orange band that was collected. The solvent was evaporated under reduced pressure and the product was recrystallized by slow diffusion of petroleum ether in a DCM solution of the product, 
affording $0.364 \mathrm{~g}(50 \%$ yield $)$ of dark red microcrystals of 3. M.p. 160-163 ${ }^{\circ} \mathrm{C}$. $\mathrm{C}_{34} \mathrm{H}_{26} \mathrm{O}_{4}\left(498.57 \mathrm{~g} \mathrm{~mol}^{-1}\right)$ : calcd. C 81.91, H 5.26, O 12.84; found C 81.55, H 5.15, O 12.62. IR (KBr, cm ${ }^{-1}$ ): 3414 (w) asym(-OH), 3100 (w) (C-H arom), 2900 (w) (C-H aliph), 1658 (m), $1598(\mathrm{~m})(\mathrm{C}=\mathrm{O})$ and/or $(\mathrm{C}=\mathrm{C}), 760(\mathrm{~m})(\mathrm{C}-\mathrm{H}) .{ }^{1} \mathrm{H} \mathrm{NMR}\left(500 \mathrm{MHz}, \mathrm{CDCl}_{3}, 25^{\circ} \mathrm{C}\right): \delta 3.91(\mathrm{~s}$, $\left.3 \mathrm{H}, \mathrm{CH}_{3}\right), 5.97$ (s, $\left.1 \mathrm{H}, \mathrm{H}-7\right), 6.46\left(\mathrm{~d},{ }^{4} J_{\mathrm{H}, \mathrm{H}}=1.75 \mathrm{~Hz}, 1 \mathrm{H}, \mathrm{H}-3\right), 6.81$ (s, $1 \mathrm{H}, \mathrm{CH}$ acac), 6.99 $\left(\mathrm{d},{ }^{3} J_{\mathrm{H}, \mathrm{H}}=8.9 \mathrm{~Hz}, 2 \mathrm{H}, \mathrm{C}_{6} H_{4}-\mathrm{OCH}_{3}\right), 7.07\left(\mathrm{~d},{ }^{4} J_{\mathrm{H}, \mathrm{H}}=1.75 \mathrm{~Hz}, 1 \mathrm{H}, \mathrm{H}-5\right), 7.47\left(\mathrm{t},{ }^{3} J_{\mathrm{H}, \mathrm{H}}=7.5\right.$ $\mathrm{Hz}, 2 \mathrm{H}, \mathrm{H}-24,64), 7.46\left(\mathrm{~m},{ }^{3} J_{\mathrm{H}, \mathrm{H}}=7.5\right.$ and $7.8 \mathrm{~Hz}, 4 \mathrm{H}, \mathrm{H}-23,25$ and H-63,65), 7.49 (d, ${ }^{3} J_{\mathrm{H}, \mathrm{H}}$ $=8.5 \mathrm{~Hz}, 2 \mathrm{H}, \mathrm{H}-9,13), 7.77\left(\mathrm{~d},{ }^{3} J_{\mathrm{H}, \mathrm{H}}=7.8 \mathrm{~Hz}, 4 \mathrm{H}, \mathrm{H}-22,26\right.$ and H-62,66), $7.97\left(\mathrm{~d},{ }^{3} J_{\mathrm{H}, \mathrm{H}}=\right.$ $8.5 \mathrm{~Hz}, 2 \mathrm{H}, \mathrm{H}-10,12), 7.99\left(\mathrm{~d},{ }^{3} J_{\mathrm{H}, \mathrm{H}}=8.9 \mathrm{~Hz}, 2 \mathrm{H}, \mathrm{C}_{6} H_{4}-\mathrm{OCH}_{3}\right), 17.09$ (s, $\left.1 \mathrm{H}, \mathrm{OH}\right) .{ }^{13 \mathrm{C}}\left\{{ }^{1} \mathrm{H}\right\}$ NMR (125 MHz, $\left.\mathrm{CDCl}_{3}, 25^{\circ} \mathrm{C}\right): \delta 55.5\left(\mathrm{CH}_{3}\right), 92.0$ (C-H acac), 102.0 (C-3), 108.7 (C-5), 113.2 (C-7), $113.9\left(\mathrm{C}-\mathrm{H} C_{6} \mathrm{H}_{4}-\mathrm{OCH}_{3}\right), 124.6$ (C-22,26), 125.0 (C-62,66), 127.4 (C-10,12), $127.6(\mathrm{C}-9,13), 128.5\left(\mathrm{C}_{\text {quat }} C_{6} \mathrm{H}_{4}-\mathrm{C}=\mathrm{O}\right), 128.7(\mathrm{C}-63,65), 128.7(\mathrm{C}-23,25), 129.2\left(\mathrm{C}-\mathrm{H} C_{6} \mathrm{H}_{4}-\right.$ $\mathrm{OCH}_{3}$ ), 129.3 (C-64), 129.6 (C-24), 131.5 (C-4), 132.0 (C-11), 133.0 (C-61), 133.2 (C-21), 143.0 (C-8), $151.6(\mathrm{C}-6), 153,6(\mathrm{C}-2), 163.1\left(\mathrm{C}-\mathrm{OCH}_{3}\right), 183.6(\mathrm{C}-\mathrm{OH}), 185.6(\mathrm{C}=\mathrm{O})$.

4.4. Synthesis of 1-(4-((2,6-diphenyl-4H-pyran-4-ylidene)methyl)phenyl)-3(ferrocenyl)propane-1,3-dione (4)

A Schlenk tube was charged with a magnetic stir bar, acetylferrocene $(0.32 \mathrm{~g}, 1.457 \mathrm{mmol})$, potassium tert-butoxide $(0.250 \mathrm{~g}, 2.23 \mathrm{mmol})$ and $3.0 \mathrm{~mL}$ of THF. After $15 \mathrm{~min}$ of stirring, a light brown precipitate formed and the reaction mixture was vigorously stirred for $2 \mathrm{~h}$ before a solid sample of compound $2(1.1 \mathrm{~g}, 2.89 \mathrm{mmol})$ was slowly added. After $10 \mathrm{~min}$ of stirring, $2.0 \mathrm{~mL}$ of THF were added and the vigorous stirring was continued for $15 \mathrm{~h}$. The reaction was quenched with water and partitioned between water and DCM (3 x $50 \mathrm{~mL})$. The combined organic extracts were dried over $\mathrm{MgSO}_{4}$, concentrated and adsorbed on a column packed with silica gel. Elution with petroleum ether-DCM mixture (4:6) produced the release of a dark red band that was collected. The solvent was evaporated under reduced pressure and the product was recrystallized by slow diffusion of petroleum ether into a DCM solution of the product, affording $0.420 \mathrm{~g}$ (50\% yield) of dark red microcrystals of 4 . A crystal from this crop was used for X-ray structure determination. M.p. $90-93{ }^{\circ} \mathrm{C} . \mathrm{C}_{37} \mathrm{H}_{28} \mathrm{O}_{3} \mathrm{Fe} \cdot 0.1 \mathrm{CH}_{2} \mathrm{Cl}_{2}(584.53 \mathrm{~g}$ $\mathrm{mol}^{-1}$ ): calcd. C 76.16, $\mathrm{H} 4.82$; found C 76.56, H 4.86. IR $\left(\mathrm{KBr}, \mathrm{cm}^{-1}\right): 3446(\mathrm{w})$ asym (-OH), 3088 (w) (C-H arom), 2965 (w) (C-H aliph), 1656 (m), 1578 (m) (C=O) and/or (C=C), 764 (m) (C-H). ${ }^{1} \mathrm{H}$ NMR $\left(500 \mathrm{MHz}, \mathrm{CDCl}_{3}, 25^{\circ} \mathrm{C}\right): \delta 4.23\left(\mathrm{~s}, 5 \mathrm{H}, \mathrm{C}_{5} \mathrm{H}_{5}\right), 4.59$ (br t, ${ }^{3} J_{\mathrm{H}, \mathrm{H}}=1.6$ $\left.\mathrm{Hz}, 2 \mathrm{H}, \mathrm{C}_{5} \mathrm{H}_{4}\right), 4.90\left(\mathrm{br} \mathrm{t},{ }^{3} J_{\mathrm{H}, \mathrm{H}}=1.6 \mathrm{~Hz}, 2 \mathrm{H}, \mathrm{C}_{5} \mathrm{H}_{4}\right), 5.98$ (s, $\left.1 \mathrm{H}, \mathrm{H}-7\right), 6.41(\mathrm{~s}, 1 \mathrm{H}, \mathrm{C}-\mathrm{H}$ 
acac), 6.49 (s, 1 H, H-3), 7.09 (s, 1 H, H-5), 7.41-7.51 (m, 8 H, H-9,13, H-23,24,25 and H63,64,65), $7.79\left(\mathrm{~d},{ }^{3} J_{\mathrm{H}, \mathrm{H}}=7.3 \mathrm{~Hz}, 4 \mathrm{H}, \mathrm{H}-22,26\right.$ and H-62,66), $7.93\left(\mathrm{~d},{ }^{3} J_{\mathrm{H}, \mathrm{H}}=7.8 \mathrm{~Hz}, 2 \mathrm{H}, \mathrm{H}-\right.$ 10,12), $16.82(\mathrm{~s}, 1 \mathrm{H}, \mathrm{OH}) .{ }^{13} \mathrm{C}\left\{{ }^{1} \mathrm{H}\right\}$ NMR $\left(125 \mathrm{MHz}, \mathrm{CDCl}_{3}, 25^{\circ} \mathrm{C}\right): \delta 68.6\left(\mathrm{C}_{5} \mathrm{H}_{4}\right), 70.3$ $\left(\mathrm{C}_{5} \mathrm{H}_{5}\right), 72.3\left(\mathrm{C}_{5} \mathrm{H}_{4}\right), 77.3\left(\mathrm{C}_{\mathrm{ipso}} \mathrm{C}_{5} \mathrm{H}_{4}\right), 93.2$ (=C-H acac), 101.8 (C-3), $108.5(\mathrm{C}-5), 113.0(\mathrm{C}-$ 7), 124.5, 124.8, 126.9, 127.5, 128.7, 129.3, 129.6, (C-H arom), 131.2 (C-4), 132.9, 136.6, 137.2 (C-11, C-21, C-61), 142.5 (C-8), 151.2, 153.2 (C-2/C-6), 178.4 (C-OH), 194.8 (C=O).

\subsection{Synthesis of 1-acétyl-1'-[(2,6-diphenyl-4H-pyran-4-ylidene)methyl] ferrocene (6)}

A Schlenk tube was charged with a magnetic stirbar, acetyl chloride $(0.26 \mathrm{~mL}, 3.50 \mathrm{mmol})$, aluminum trichloride $(0.470 \mathrm{~g}, 3.50 \mathrm{mmol})$ and DCM $(20.0 \mathrm{~mL})$. The resulting mixture was stirred for $2 \mathrm{~h}$ at rt and added dropwise to a solution of ferrocenyl-methylenepyran 5 (0.500 g, $1.16 \mathrm{mmol})$ in freshly distilled $\mathrm{CH}_{2} \mathrm{Cl}_{2}(100 \mathrm{~mL})$, under $\mathrm{N}_{2}$ at $0^{\circ} \mathrm{C}$. The reaction mixture was stirred for $2 \mathrm{~h}$, quenched with water $(100 \mathrm{~mL})$, and extracted with DCM. The organic phase was collected, neutralized with a $0.1 \mathrm{M}$ aqueous solution of $\mathrm{Na}_{2} \mathrm{CO}_{3}$, and dried over $\mathrm{MgSO}_{4}$. The solvent was evaporated under reduced pressure to give compound $\mathbf{6}$ as a red microcrystalline powder $(0.350 \mathrm{~g}, 61 \%$ yield $)$. The product was recrystallized by slow diffusion of diethyl ether into a DCM solution of the complex. M.p 116-118 ${ }^{\circ} \mathrm{C}$. HRMS-ESI ${ }^{+}$ (based on ${ }^{56} \mathrm{Fe}$ ) $\mathrm{C}_{30} \mathrm{H}_{24} \mathrm{O}_{2} \mathrm{NaFe}\left[\mathrm{M}^{+} \mathrm{Na}\right] \mathrm{m} / \mathrm{z}$ calcd: 495.1023 ; found: 495.1023 (0 ppm). IR $\left(\mathrm{KBr}, \mathrm{cm}^{-1}\right)$ : 1657 (s) (C=O), $1601(\mathrm{w}), 1579$ (w) (C=C), 1493 (w), 1448 (w) (C-H), 822 (br), $762(\mathrm{~s}), 687(\mathrm{~s})(\mathrm{C}-\mathrm{H}) .{ }^{1} \mathrm{H}$ NMR $\left(500 \mathrm{MHz}, \mathrm{CDCl}_{3}, 25^{\circ} \mathrm{C}\right): \delta 2.36\left(\mathrm{~s}, 3 \mathrm{H}, \mathrm{CH}_{3}\right), 4.29\left(\mathrm{t},{ }^{3} J_{\mathrm{H}, \mathrm{H}}\right.$ $\left.=1.6 \mathrm{~Hz}, 2 \mathrm{H}, \mathrm{C}_{5} \mathrm{H}_{4}\right), 4.43\left(\mathrm{t},{ }^{3} J_{\mathrm{H}, \mathrm{H}}=1.6 \mathrm{~Hz}, 2 \mathrm{H}, \mathrm{C}_{5} \mathrm{H}_{4}\right), 4.49\left(\mathrm{t},{ }^{3} J_{\mathrm{H}, \mathrm{H}}=1.8 \mathrm{~Hz}, 2 \mathrm{H}\right.$, $\left.\mathrm{C}_{5} \mathrm{H}_{4} \mathrm{COCH}_{3}\right), 4.76\left(\mathrm{t},{ }^{3} J_{\mathrm{H}, \mathrm{H}}=1.8 \mathrm{~Hz}, 2 \mathrm{H}, \mathrm{C}_{5} H_{4} \mathrm{COCH}_{3}\right), 5.46(\mathrm{~s}, 1 \mathrm{H}, \mathrm{H}-7), 6.34(\mathrm{~s}, 1 \mathrm{H}, \mathrm{H}-$ 3), 6.80 (s, $1 \mathrm{H}, \mathrm{H}-5), 7.43-7.45$ (m, 6 H, H-23,24,25 and H-63,64,65), 7.76-7.69 (m, 4 H,H22,26 and H-62,66). ${ }^{13} \mathrm{C}$ NMR (125 MHz, $\left.\mathrm{CDCl}_{3}, 25^{\circ} \mathrm{C}\right)$ : $\delta 27.7\left(\mathrm{CH}_{3}\right), 69.3,70.0(\mathrm{C}-\mathrm{H}$, $\left.\mathrm{C}_{5} \mathrm{H}_{4}\right), 70.4,73.4$ (C-H, $\left.\mathrm{C}_{5} \mathrm{H}_{4} \mathrm{COCH}_{3}\right), 79.9,86.5\left(\mathrm{C}_{\mathrm{ipso}} \mathrm{C}_{5} \mathrm{H}_{4}\right), 103.4$ (C-3), 107.9 (C-5), 109.3 (C-7), 124.3, 124.7, 128.5, 128.6, 128.8, 129.2 (C-H arom), 132.0 (C-4), 133.3 (C-61), 133.5 (C-21), 149.8 (C-6), $152.0(\mathrm{C}-2), 202.1(\mathrm{C}=\mathrm{O})$.

4.6. Synthesis of 1-(1,3-dioxobutyl)-1'-[(2,6-diphenyl-4H-pyran-4-ylidene)methyl] ferrocene (7)

A Schlenk tube was charged with a solution of di-isopropylamine $(576 \mu \mathrm{L}, 4.10 \mathrm{mmol})$ in diethyl ether $(4.0 \mathrm{~mL})$ to which was added dropwise $n$-butyl lithium $(1.6 \mathrm{~mL}, 4.0 \mathrm{mmol})$ at 0 ${ }^{\circ} \mathrm{C}$. The resulting mixture was stirred for $1 \mathrm{~h}$ before solid sample 1-acetyl-1'- 
methylenepyrane-ferrocene $6(0.500 \mathrm{~g}, 1.0 \mathrm{mmol})$ was slowly added. The reaction mixture was stirred overnight at room temperature (r.t.). Upon cooling to $0^{\circ} \mathrm{C}$, ethyl acetate $(1.0 \mathrm{~mL}$, $10.2 \mathrm{mmol}$ ) was added dropwise over a $30 \mathrm{~min}$ period, and the resulting solution was stirred overnight at r.t. The reaction mixture was hydrolysed with $1 \mathrm{M}$ aqueous $\mathrm{HCl}(20 \mathrm{~mL})$ and 50 $\mathrm{mL}$ of water, and extracted with $\mathrm{CH}_{2} \mathrm{Cl}_{2}$. The combined organic extracts were dried over $\mathrm{MgSO}_{4}$ and the solvent was evaporated to dryness. The solid residue was dissolved in a minimum amount of DCM and absorbed on a column packed with silica gel (grade 60). Elution with petroleum ether-diethyl ether (1:4) produced the release of a red band that was collected. The solvent was evaporated under reduced pressure, affording $105 \mathrm{mg}$ (20\% yield) of 7 as an orange powder. M.p 132-134 ${ }^{\circ} \mathrm{C}$. HRMS-ESI ${ }^{+}$(based on ${ }^{56} \mathrm{Fe}$ ) $\mathrm{C}_{32} \mathrm{H}_{26} \mathrm{O}_{3} \mathrm{Fe}[\mathrm{M}]^{+}$. m/z calcd: 514.1231 ; found: 514.1228 (1 ppm). IR (KBr, cm $\left.{ }^{-1}\right): 3440(\mathrm{br})(\mathrm{O}-\mathrm{H}), 1729(\mathrm{~m})$, $1655(\mathrm{~m}), 1628(\mathrm{~m}), 1602(\mathrm{~m}), 1585(\mathrm{~m})(\mathrm{C}=\mathrm{O})$ and/or (C=C), 1262-1026 (m) (C-O), $800(\mathrm{~m})$ and $760(\mathrm{~m})(\mathrm{C}-\mathrm{H}) .{ }^{1} \mathrm{H}$ NMR $\left(500 \mathrm{MHz}, \mathrm{CDCl}_{3}, 25^{\circ} \mathrm{C}\right)$ : Enol form $(73 \%) \delta 1.93(\mathrm{~s}, 3 \mathrm{H}$, $\left.\mathrm{CH}_{3}\right), 4.28\left(\mathrm{t},{ }^{3} J_{\mathrm{H}, \mathrm{H}}=1.4 \mathrm{~Hz}, 2 \mathrm{H}, \mathrm{C}_{5} \mathrm{H}_{4}\right), 4.43\left(\mathrm{t},{ }^{3} J_{\mathrm{H}, \mathrm{H}}=1.4 \mathrm{~Hz}, 2 \mathrm{H}, \mathrm{C}_{5} \mathrm{H}_{4}\right), 4.48\left(\mathrm{t},{ }^{3} J_{\mathrm{H}, \mathrm{H}}=\right.$ $\left.1.5 \mathrm{~Hz}, 2 \mathrm{H}, \mathrm{C}_{5} \mathrm{H}_{4}\right), 4.76\left(\mathrm{t},{ }^{3} J_{\mathrm{H}, \mathrm{H}}=1.6 \mathrm{~Hz}, 2 \mathrm{H}, \mathrm{C}_{5} \mathrm{H}_{4}\right), 5.38(\mathrm{~s}, 1 \mathrm{H}, \mathrm{H}-7), 5.65(\mathrm{~s}, 1 \mathrm{H}, \mathrm{CH}$ acac), 6.27 (s, $1 \mathrm{H}, \mathrm{H}-3), 6.78$ (s, $1 \mathrm{H}, \mathrm{H}-5), 7.39-7.43$ (m, $6 \mathrm{H}, \mathrm{H}-23,24,25$ and H-63,64,65), 7.69-7.76 (m, 4 H, H-22,26 and H-62,66), 15.98 (s, 1 H, OH); Keto form (27\%) $\delta 2.28$ (s, 3 $\left.\mathrm{H}, \mathrm{CH}_{3}\right), 3.81\left(\mathrm{~s}, 2 \mathrm{H}, \mathrm{CH}_{2}\right), 4.32\left(\mathrm{~s}, 2 \mathrm{H}, \mathrm{C}_{5} \mathrm{H}_{4}\right), 4.46\left(\mathrm{~s}, 2 \mathrm{H}, \mathrm{C}_{5} \mathrm{H}_{4}\right), 4.54\left(\mathrm{~s}, 2 \mathrm{H}, \mathrm{C}_{5} \mathrm{H}_{4}\right), 4.76$ (s, $2 \mathrm{H}, \mathrm{C}_{5} \mathrm{H}_{4}$ ), 5.45 (s, $\left.1 \mathrm{H}, \mathrm{H}-7\right), 6.35$ (s, $\left.1 \mathrm{H}, \mathrm{H}-3\right), 6.79$ (s, $\left.1 \mathrm{H}, \mathrm{H}-5\right), 7.38-7.40$ (m, $6 \mathrm{H}, \mathrm{H}-$ 23,24,25 and H-63,64,65), 7.52-7.54, 7.69-7.71 (2 x m, 2 x $2 \mathrm{H}, \mathrm{H}-22,26$ and H-62,66). ${ }^{13} \mathrm{C}$ NMR (125 MHz, $\left.\mathrm{CDCl}_{3}, 25^{\circ} \mathrm{C}\right)$ : Enol form $(73 \%) \delta 24.0\left(\mathrm{CH}_{3}\right) 69.5\left(\mathrm{C}_{5} \mathrm{H}_{4}\right), 69.6\left(\mathrm{C}_{5} \mathrm{H}_{4}\right)$, $70.3\left(\mathrm{C}_{5} \mathrm{H}_{4}\right), 72.7\left(\mathrm{C}_{5} \mathrm{H}_{4}\right), 78.3\left(\mathrm{C}_{\mathrm{ipso}} \mathrm{C}_{5} \mathrm{H}_{4}\right), 86.1\left(\mathrm{C}_{\mathrm{ipso}} \mathrm{C}_{5} \mathrm{H}_{4}\right), 97.6\left(\mathrm{CH}_{3} \mathrm{C}(\mathrm{OH})=C \mathrm{H}\right), 102.8$ (C-3), 108.4 (C-5), 108.9 (C-7), 124.4, 124.8, 128.6, 128.7, 128.8, 128.9 (C-H arom), 132.5 (C-4), 133.4 (C-61), 133.7 (C-21), 149.6 (C-6), $151.9(\mathrm{C}-2), 187.1\left(\mathrm{CH}_{3}-\mathrm{C}(\mathrm{OH})=\right), 192.2(\mathrm{Cp}-$ $\mathrm{C}=\mathrm{O})$; Keto form $(27 \%) \delta 30.7\left(\mathrm{CH}_{3}\right), 56.6\left(\mathrm{CH}_{2}\right), 69.4\left(\mathrm{C}_{5} \mathrm{H}_{4}\right), 70.3\left(\mathrm{C}_{5} \mathrm{H}_{4}\right), 70.7\left(\mathrm{C}_{5} \mathrm{H}_{4}\right)$, $74.3\left(\mathrm{C}_{5} \mathrm{H}_{4}\right), 102.6$ (C-3), 108.3 (C-5), 108.8 (C-7), 124.5, 124.9, 128.7 (C-H arom), 197.8 $(\mathrm{Cp}-\mathrm{CO}), 202.3\left(\mathrm{CH}_{3}-\mathrm{C}=\mathrm{O}\right)$.

\subsection{X-ray crystal structure determinations}

X-ray data for single crystals of compounds $\mathbf{2}, \mathbf{4}$ and $\mathbf{6}$, obtained as described above, were collected at 150(2) $\mathrm{K}$ on a Bruker APEXII AXS diffractometer, equipped with a CCD detector, using Mo-K $\alpha$ radiation $(\lambda=0.71073 \AA$ ). For each compound, a crystal of appropriate size and shape was selected and coated in Paratone- $\mathrm{N}$ oil and mounted on a 
Kaptan loop. The loop was transferred to the diffractometer, centered in the beam, and cooled by a nitrogen flow low-temperature apparatus that had been previously calibrated by a thermocouple placed at the same position as the crystal. The structures were solved by direct methods using SIR97 program [55], and then refined with full-matrix least-square methods based on $F^{2}$ (SHELXL-97) [56], with the help of WINGX program [57]. All non-hydrogen atoms were refined with anisotropic atomic displacement parameters. Hydrogen atoms were finally included in their calculated positions. The disorder observed for the carbon atoms of the free cyclopentadienyl ring in $\mathbf{4}$ was modelled using two positions per carbon with fixed 0.71 and 0.29 occupancy factors for each carbon. A summary of the details about crystal data, collection parameters and refinement are documented in Table 3, and additional crystallographic details are in the CIF files. ORTEP and Ball-and-Stick views are generated using OLEX2 [58]. 
Table 3 Crystallographic data, details of data collection and structure refinement parameters for compounds 2,4 and 6

\begin{tabular}{|c|c|c|c|}
\hline & 2 & 4 & 6 \\
\hline Empirical formula & $\mathrm{C}_{52} \mathrm{H}_{40} \mathrm{O}_{6}$ & $\mathrm{C}_{37} \mathrm{H}_{28} \mathrm{FeO}_{3}$ & $\mathrm{C}_{30} \mathrm{H}_{24} \mathrm{FeO}_{2}$ \\
\hline Formula mass, $\mathrm{g} \mathrm{mol}^{-1}$ & 760.84 & 576.44 & 472.34 \\
\hline Collection $\mathrm{T}, \mathrm{K}$ & $150(2)$ & $150(2)$ & $150(2)$ \\
\hline Crystal system & Monoclinic & Monoclinic & Monoclinic \\
\hline space group & $P 2_{1} / n$ & $P 2_{1} / n$ & $P 2_{1} / n$ \\
\hline $\mathrm{a}(\AA)$ & $7.0936(14)$ & $12.5310(8)$ & $5.8457(7)$ \\
\hline $\mathrm{b}(\AA)$ & $30.623(6)$ & $5.8917(3)$ & $31.725(5)$ \\
\hline$c(\AA)$ & $17.892(3)$ & $36.617(2)$ & $11.9626(17)$ \\
\hline$\beta\left(^{\circ}\right)$ & $101.327(6)$ & $98.574(3)$ & $96.648(5)$ \\
\hline $\mathrm{V}\left(\AA^{3}\right)$ & $3810.9(12)$ & $2673.2(3)$ & $2203.6(5)$ \\
\hline $\mathrm{Z}$ & 4 & 4 & 4 \\
\hline $\mathrm{D}_{\text {calcd }}\left(\mathrm{g} \mathrm{cm}^{-3}\right)$ & 1.326 & 1.432 & 1.424 \\
\hline Crystal size (mm) & $0.32 \times 0.31 \times 0.07$ & $0.6 \times 0.14 \times 0.09$ & $0.6 \times 0.09 \times 0.08$ \\
\hline $\mathrm{F}(000)$ & 1600 & 1200 & 984 \\
\hline $\operatorname{abs} \operatorname{coeff}\left(\mathrm{mm}^{-1}\right)$ & 0.086 & 0.603 & 0.711 \\
\hline$\theta$ range $\left(^{\circ}\right)$ & 2.93 to 27.48 & 3.04 to 27.48 & 3.09 to 27.48 \\
\hline range $\mathrm{h}, \mathrm{k}, \mathrm{l}$ & $-8 / 9,-39 / 39,-23 / 23$ & $-16 / 16,-5 / 7,-47 / 47$ & $-4 / 7,-41 / 41,-15 / 15$ \\
\hline No. total refl & 55291 & 23189 & 17651 \\
\hline No. unique refl & 8559 & 6099 & 5002 \\
\hline Comp. to $\theta_{\max }(\%)$ & 97.3 & 99.3 & 98.9 \\
\hline Max/min transmission & $0.994 / 0.833$ & $0.947 / 0.761$ & $0.945 / 0.843$ \\
\hline Data/Restraints/Parameters & $8559 / 0 / 448$ & $6099 / 30 / 387$ & $5002 / 0 / 299$ \\
\hline Final $\mathrm{R}$ & $\mathrm{R}_{1}=0.0582$ & $\mathrm{R}_{1}=0.0426$ & $\mathrm{R}_{1}=0.0416$ \\
\hline$[\mathrm{I}>2 \sigma(\mathrm{I})]$ & $\mathrm{wR}_{2}=0.1252$ & $\mathrm{wR}_{2}=0.0885$ & $\mathrm{wR}_{2}=0.0870$ \\
\hline \multirow[t]{2}{*}{$\mathrm{R}$ indices (all data) } & $\mathrm{R}_{1}=0.1450$ & $\mathrm{R}_{1}=0.0769$ & $\mathrm{R}_{1}=0.0660$ \\
\hline & $\mathrm{wR}_{2}=0.1598$ & $\mathrm{wR}_{2}=0.1014$ & $\mathrm{wR}_{2}=0.0967$ \\
\hline Gof / $\mathrm{F}^{2}$ & 1.016 & 1.025 & 1.058 \\
\hline Largest diff. Peak/hole $\left(\mathrm{e} \AA^{-3}\right)$ & $0.265 /-0.276$ & $0.307 /-0.495$ & $0.377 /-0.338$ \\
\hline
\end{tabular}




\section{Acknowledgments}

The authors thank Drs S. Sinbandhit and P. Jehan (CRMPO, Rennes) for NMR and HRMS experiments, respectively. We are grateful to N. Kervarec, S. Cerantola and G. Simon for recording NMR spectra (Service Commun de Recherche de RMN et de RPE, Université de Bretagne Occidentale, Brest). This research has been performed as part of the Chilean-French International Associated Laboratory for "Inorganic Functional Materials"' (LIAMIF-CNRS $\left.N^{\circ} 836\right)$. Financial support from the Fondo Nacional de Desarrollo Científico y Tecnológico [FONDECYT (Chile), grant no. 1090310 (C.M. and D.C.)], the Vicerrectoría de Investigación y Estudios Avanzados, Pontificia Universidad Católica de Valparaíso, Chile (C.M. and D.C.), the CNRS, the MESR and the Université de Rennes 1 is gratefully acknowledged. N.N. thanks the CONICYT (Chile) for support of a graduate fellowship and the French Embassy in Chile for the 2011 scholarship awarded doctoral internship.

\section{Appendix A. Supplementary material}

CCDC 949438 - 949440 contains the supplementary crystallographic data for this paper. These data can be obtained free of charge from The Cambridge Crystallographic Data Centre via www.ccdc.cam.ac.uk/data_request/cif.

\section{Appendix B. Supplementary material}

Bond distances and angles of the methylenepyran core for complexes 2, 4, and 6; packing diagram for $\mathbf{4}$ and cyclic voltammograms for complexes $\mathbf{2}, \mathbf{3}$, and $\mathbf{6}$. 


\section{References}

[1] L. Claisen, E.F. Ehrhardt, Ber. Dtsch. Chem. Ges. 22 (1889) 1009-1019.

[2] H. Meerwein, Ber. Dtsch. Chem. Ges. 66 (1933) 411-414.

[3] (a) R. MR. Pike, Coord. Chem. Rev. 2 (1967) 163-172;

(b) D. Gibson, Coord. Chem. Rev. 4 (1969) 225-240.

[4] A.V. Kel'-in, Curr. Org. Chem. 7 (2003) 1691-1711 and references therein.

[5] (a) A.V.F.G. Young, F.C. Frostick, Jr., J.J. Sanderson, C.R. Hauser, J. Am. Chem. Soc. $72 \quad$ (1950) $3635-3642$;

(b) A.R. Katritzky, A. Pastor, J. Org. Chem. 65 (2000) 3679-3682;

(c) D. Kalaitzakis, J.D. Rozzell, I. Smonou, S. Kambourakis, Adv. Synth. Catal. 348 (2006) 1958-1969.

[6] J. Schranck, A. Tlili, P.G. Alsabeh, H. Neumann, M. Stradiotto, M. Beller, Chem. Eur. J. 19 (2013) 12624-12628.

[7] (a) C.R. Hauser, J.K. Lindsay, J. Org. Chem. 22 (1957) 482-485;

(b) C.R. Hauser, C.E. Cain, J. Org. Chem. 23 (1958) 1142-1146;

(c) C.E. Cain, T.A. Mashburn, C.R. Hauser, J. Org. Chem. 26 (1961) 1030-1034.

[8] V. Weinmayr, Naturwissenchaften 45 (1958) 311.

[9] T.J. Kealy, P.L. Pauson, Nature 168 (1951) 1039-1041.

[10] K.C. Kemp, E. Fourie, J. Conradie, J.C. Swarts, Organometallics 27 (2008) 353-362.

[11]J. Emsley, Struct. Bonding 57 (1984) 147-191.

[12]E. Iglesias, J. Org. Chem. 68 (2003) 2680-2688.

[13]W.C. du Plessis, W.L. Davis, S.J. Cronje, J.C. Swarts, Inorg. Chim. Acta 314 (2001) 97104.

[14]W.C. Du Plessis, T.G. Vosloo, J.C. Swarts, J. Chem. Soc., Dalton Trans. (1998) 25072514.

[15]W.C. du Plessis, J.J.C. Erasmus, G.J. Lamprecht, J. Conradie, T.S. Cameron, M.A.S. Aquino, J.C. Swarts, Can. J. Chem. 77 (1999) 378-386.

[16]W. Bell, J.A. Crayston, C. Glidewell, M.A. Mazid, M.B. Hursthouse, J. Organomet. Chem. 434 (1992) 115-121. 
[17]S. Celedon, M. Fuentealba, T. Roisnel, J.-R. Hamon, D. Carrillo, C. Manzur, Inorg. Chim. Acta 390 (2012) 184-189.

[18](a) G. Gilli, F. Bellucci, V. Ferretti, V. Bertolasi, J. Am. Chem. Soc. 111 (1989) 10231028 ;

(b) V. Bertolasi, P. Gilli, V. Ferretti, G. Gilli, J. Am. Chem ; Soc. 113 (1991) 4917-4925.

[19] Y. Shang, B. Li, R. Hu, Y. Su, Q. Tang, Acta Crystallogr. E63 (2007) m3020.

[20]E.V. Shchegol'kov, Y.V. Burgart, O.G. Khudina, V.I. Saloutin, O.N. Chupakhin, Russ. Chem. Rev. 79 (2010) 31-61.

[21]F.H. Osman, F.A. El-Samahy, Chem. Rev. 102 (2002) 629-678.

[22] T. Harschneck, S. Hummel, S.F. Kirsch, P. Klahn, Chem. Eur. J. 18 (2012) 1187-1193.

[23] S. Fustero, M. Sanchez-Rosello, P. Barrio, A. Simon-Fuentes, Chem. Rev. 111 (2011) 6984-7034.

[24] Y.L. Janin, Chem. Rev. 112 (2012) 3924-3958.

[25](a) P. Guerriero, S. Tamburini, P.A. Vigato, Coord. Chem. Rev. 139 (1995) 17-243;

(b) P.A. Vigato, S. Tamburini, Coord. Chem. Rev. 248 (2004) 1717-2128;

(c) P.A. Vigato, V. Peruzzo, S. Tamburini, Coord. Chem. Rev. 256 (2012) 953-1114.

[26](a) F.P. Dwyer, DP.Mellor, Chelating Agents and Metal Chelates Academic Press, London,

1964

(b) A.R. Siedle, in: G. Wilkinson, R. D. Gillard, J. A. McCleverty (Eds.), Comprehensive Coordination Chemistry vol. 2, Pergamon Press, Oxford, 1987, pp. 365412;

(c) F. Marchetti, C. Pettinari, R. Pettinari, Coord. Chem. Rev. 249 (2005) 2909-2945 and Ref. [3] cited therein.

[27](a) S. Kawaguchi, Coord. Chem. Rev. $70 \quad$ (1986) 51-84;(

b) P.A. Vigato, V. Peruzzo, S. Tamburini, Coord. Chem. Rev. 253 (2009) 1099-1201;

(c) K.T. Mahmudov, M.N. Kopylovich, A.J.L. Pombeiro, Coord. Chem. Rev. 257 (2013) $1244-1281$.

[28](a) U. Casellato, M. Vidali, PA. Vigato, Inorg. Chim. Acta 18 (1976) 77-112;

(b) C. Piguet, J.-C.G. Büzli, Chem. Soc. Rev. 28 (1999) 347-358;

(c) K. Binnemans, Chem. Rev. 109 (2009) 4283-4374. 
[29](a) H. Hagen, J. Boersma, G. van Koten, Chem. Soc. Rev. 31 (2002) 357-364;

(b) M.R. Maurya, Coord. Chem. Rev. 237 (2003) 163-181.

[30](a) F. Pointillart, B. Le Guennic, S. Golhen, O. Cador, O. Maury, L. Ouahab, Chem. Commun.

(b) Y. Wang, B. Li, G. Huang, J.-P. Zhang, Y. Zhang, New J. Chem. 35 (2011) 14721476.

[31](a) D.J. Bray, J.K. Clegg, L.F. Lindoy, D. Schilter, Adv. Inorg. Chem. 59 (2007) 1-36;

(b) G. Aromí, P. Gamez, J. Reedijk, Coord. Chem. Rev. 252 (2008) 964-989.

[32](a) P.A. Albouy, J.P. Pouget, H. Strzelecka, Phys. Rev. 35 (1987) 173-188;

(b) H. Strzelecka, R. Vicente, J. Ribas, J.-P. Legros, P. Cassoux, P. Petit, J.-J. Andre, Polyhedron 10 (1991) 687-695.

[33](a) M.R. Detty, S.L. Gibson, Organometallics $11 \quad$ (1992) 2147-2156;

(b) M.R. Detty, P.B. Merkel, J. Am. Chem. Soc. 112 (1990) 3845-3855.

[34] (a) R. Fugnitto, H. Strzelecka, A. Zann, J.-C. Dubois, J. Billard, J. Chem. Soc., Chem. Commun. (1980)

271-272;

(b) F.D. Savea, G.A. Reynolds, L. Kaszcuk, J. Am. Chem. Soc. 104 (1982) 3524-3525.

[35](a) S. Beckmann, K.-H. Etzbach, P. Kramer, K. Lukaszuk, R. Matschiner, A.J. Schmidt, P. Schumacher, R. Sens, G. Seybold, R. Wortmann, F. Wurthner, Adv. Mater. 11 (1999) 536-541;

(b) L. Yongjun, L. Ying, Z. Xian, L. Chengbu, Int. J. Quantum Chem. 82 (2001) 65-72;

(c) G. Koeckelberghs, L. De Groof, J. Perez-Moreno, I. Asselberghs, K. Clays, T. Verbiest, C. Samyn, Tetrahedron $64 \quad$ (2008) 3772-3781; (d) R. Andreu, L. Carrasquer, S. Franco, J. Garín, J. Orduna, N. Martínez de Baroja, R. Alicante, B. Villacampa, M. Allain, J.Org. Chem. 74 (2009) 6647-6657; (e) R. Andreu, E. Galán, J. Garín, V. Herrero, E. Lacarra, J. Orduna, R. Alicante, B. Villacampa, J. Org. Chem. $75 \quad$ (2010) 1684-1692; (f) R. Andreu, E. Galán, J. Orduna, B. Villacampa, R. Alicante, J.T. López Navarrete, J. Casado, J. Garín, Chem. Eur. J. $17 \quad$ (2011) 826-838; (g) E. Galán, R. Andreu, J. Garín, J. Orduna, B. Villacampa, B. Diosdado, Org. Biomol. Chem. 10 (2012) 8684-8691;

(h) A.B. Marco, R. Andreu, S. Franco, J. Garín, J. Orduna, B. Villacampa, R. Alicante, Tetrahedron 69 (2013) 3919-3926; 
(i) S. Gauthier, N. Vologdin, S. Achelle, A. Barsella, B. Caro, F. Robin-Le Guen, Tetrahedron 69 (2013)

8392-8399;

(j) S. Achelle, J.-P. Malval, S. Aloïse, A. Barsella, A. Spangenberg, L. Mager, H. AkdasKilig, J.-L. Fillaut, B. Caro, F. Robin-le Guen, Chem. Phys. Chem. 14 (2013) 2725-2736; (k) A.B. Marco, R. Andreu, S. Franco, J. Garin, J. Orduna, B. Villacampa, B.E. Diosdado, J.T. Lopez Navarette, J. Casado, Org. Biomol. Chem., 11 (2013) 6338-6349.

[36]B.L. Feringa, J. Org. Chem. 72 (2007) 6635-6652.

[37](a) M.-C. Senechal-Tocquer, M. Salmain, K.L. Maliszca, S. Top, G. Jaouen, D. Senechal, B. Caro, Bioconjugate Chem. 5 (1994) 655-659; (b) K.L. Maliska, S. Top, J. Vaisserman, B. Caro, M.-C. Sénéchal-Tocquer, D. Sénéchal, S. Triki, S. Kahlal, F. Butten, M.J. McGlinchey, G. Jaouen, Organometallics 14 (1995) 5273-5280;

(c) B. Caro, F. Robin-Le Guen, M. Salmain, G. Jaouen, Tetrahedron 56 (2000) 257-263;

(d) D. Engan, M. Salmain, P. Mc Ardel, G. Jaouen, B. Caro, Spectrochim. Acta 56 (2002) 941-951;

(e) M. Salmain, B. Caro, F. Robin-Le Guen, J.-C. Blais, G. Jaouen, Chem. Biochem. 5 (2004) 99-109.

[38](a) B. Caro, P. Le Poul, F. Robin-Le Guen, M.-C. Sénéchal-Tocquer, J. Vaisserman, Tetrahedron Lett. 39 (1998) 557-560;

(b) B. Caro, P. Le Poul, F. Robin-Le Guen, M.-C. Sénéchal-Tocquer, J.-Y. Saillard, S. Kahlal, L. Ouahab, S. Golhen, Eur. J. Org. Chem. (2000) 577-581; (c) B. Caro, P. Le Poul, F. Robin-Le Guen, J.-Y. Saillard, S. Kahlal, C. Moinet, N. Le Poul, J. Vaissermann, Tetrahedron 58 (2002) 7519-7530; (d) J.-Y. Le Bihan, N. Faux, B. Caro, F. Robin-Le Guen, P. Le Poul, J. Organomet. Chem. 692 (2007) 5517-5522.

[39] (a) F. Robin-Le Guen, P. Le Poul, B. Caro, R. Pichon, N. Kervarec, J. Organomet. Chem. 626 (2001) $37-42$;

(b) N. Faux, B. Caro, F. Robin-Le Guen, P. Le Poul, K. Nakatani, E. Ishow, J. Organomet. Chem. $690 \quad$ 4982-4988; (c) L. Milan, M. Fuentealba, C. Manzur, D. Carillo, N. Faux, B. Caro, F. Robin-Le Guen, S. Sinbandhit, I. Ledoux-Rak, J.-R. Hamon, Eur. J. Inorg. Chem. (2006) 1131-1138. 
[40] (a) F. Ba, N. Cabon, F. Robin-Le Guen, P. Le Poul, N. Le Poul, Y. Le Mest, S. Golhen, B. Caro, Organometallics $27 \quad$ (2008) 6396-6399; (b) F. Ba, F. Robin-Le Guen, N. Cabon, P. Le Poul, S. Golhen, N. Le Poul, B. Caro, J. $\begin{array}{llll}\text { Organomet. } & \text { Chem. } & \text { 235-243; }\end{array}$

(c) F. Ba, N. Cabon, P. Le Poul, S. Kahlal, J.-Y. Saillard, N. Le Poul, S. Golhen, B. Caro, F. Robin-Le Guen, New J. Chem. 37 (2013) 2066-2081.

[41]G. Ahumada, T. Roisnel, S. Sinbandhit, C. Manzur, D. Carrillo, J.-R. Hamon, J. Organomet. Chem. 737 (2013) 1-6.

[42](a) M. Fuentealba, J.-R. Hamon, D. Carrillo, C. Manzur, New J. Chem. 31 (2007) 18151825

(b) A. Trujillo, S. Sinbandhit, L. Toupet, D. Carrillo, C. Manzur, J.-R. Hamon, J. Inorg. $\begin{array}{lllll}\text { Organomet. } & \text { Polym. } & \text { Mater. } & 18 & \text { (2008) }\end{array}$ (c) A. Trujillo, M. Fuentealba, D. Carrillo, C. Manzur, J.-R. Hamon, J. Organomet. Chem. 694 1435-1440; (d) A. Trujillo, M. Fuentealba, D. Carrillo, C. Manzur, I. Ledoux-Rak, J.-R. Hamon, J.-Y. Saillard, $\quad$ Inorg. $\quad$ Chem. $49 \quad$ (2010) 2750-2764; (e) A. Trujillo, F. Justaud, L. Toupet, O. Cador, D. Carrillo, C. Manzur, J.-R. Hamon, New J. Chem. 35 (2011) 2027-2036.

[43] (a) Y.A. Zhdanov, S.V. Kriven, V.A. Polenov, Khim. Geterotsikl. Soeden. (1969) 368; (b) G.A. Reynolds, C.H. Chen, J. Org. Chem. 45 (1980) 2453-2458; (c) V.T. Abaev, L.I. Kisarova, S.E. Emanuilidi, A.A. Bumber, I.-E. Mikhailov, I.B. Blank, A.I. Yanovskii, Y.T. Struchkov, O.Y. Okhlobystin, Z. Obshchei Khim. 59 (1989) 1506-1515.

[44]R.B. Woodward, M. Rosenblum, M.C. Whiting, J. Am. Chem. Soc. 74 (1952) 34583459.

[45](a) P.R. Wells, Progress in Physical Organic Chemistry, Wiley, New York, 1968, Vol. 6, pp.

111-145;

(b) R.E. Kagarise, J. Am. Chem. Soc. 77 (1955) 1377-1379.

[46] C.-T. Chen, S.R. Marder, Adv. Mater. 7 (1995) 1030-1033.

[47]J.D. Dunitz, L.E. Orgel, A. Rich, Acta Crystallogr. 9 (1956) 373-375. 
[48](a) E. Gyepes, F. Hanic, Cryst. Struct. Commun. 4 (1975) 229-232;

(b) K. Sato, M. Iwai, H. Sano, M. Konno, Bull. Chem. Soc. Jpn. 57 (1984) 634-638;

(c) J.C. Barnes, W. Bell, C. Glidewell, R.A. Howie, J. Organomet. Chem. 385 (1990) 369-378.

[49] (a) F.H. Allen, O. Kennard, D.G. Watson, L. Brammer, A.G. Orpen, R. Taylor, J. Chem. $\begin{array}{lllll}\text { Soc., } & \text { Perkin } & \text { Trans. } & 2 & \text { (1987) }\end{array}$

(b) A.G. Orpen, L. Brammer, F.H. Allen, D. Kennard, D.G. Watson, R. Taylor, J. Chem. Soc., Dalton Trans. (1989) S1-S83.

[50](a) T. Suzuki, H. Higuchi,T. Tsuji, J. Nishida, Y. Yamashita, T. Miyashi, in: T. Nakamura, T. Matsumoto, T. Tada, K. Sugiura (Eds.), Dynamic Redox Systems, Springer, Hedelberg, 2003, Chapter 1;

(b) J.W. Canary, Chem. Soc. Rev. 38 (2009) 747-756;

(c) T. Suzuki, J.-I. Nishida, T. Tsuji, Chem. Commun. (1998) 2193-2194;

(d) N. G. Connelly, Chem. Soc. Rev. 18, (1989) 153;

(e) J.-R. Hamon, D. Astruc, P. Michaud, J. Am. Chem. Soc. 103 (1981) 758.

[51](a) P. Zanello, F. Fabrizi de Biani, C. Glidewell, J. Koenig, S.J. Marsh, Polyhedron 17 (1998)

1795-1801;

(b) A. Hildebrandt, D. Schaarschmidt, H. Lang, Organometallics 30 (2011) 556-563;

(c) J. Alvarez, Y. Ni, T. Ren, A.E. Kaifer, J. Supramol. Chem. 1 (2001) 7-16;

(d) C. Lapinte, J. Organometal. Chem. 693 (2008) 793-801.

[52]W.L.F. Armarego, C.L.L. Chai, Purification of Laboratory Chemicals, 5th ed., Butterworth-Heinemann, 2003.

[53] S.V. Krivan, O.F. Voziyanova, S.N. Baranov, Zh. Obshch. Kim. 42 (1972) 298-302; Chem. Abstr. 77 (1972) 34224.[54] A. Altomare, M.C. Burla, M. Camalli, G. Cascarano, C. Giacovazzo, A. Guagliardi, A.G.G. Moliterni, G. Polidori, R. Spagna, J. Appl. Crystallogr. 32 (1999) 115-119.

[54]Ferrocene was used here as internal standard to assure comparison with previous work [40]; however, ferrocene is far from perfect as an internal reference, see: J. Ruiz, D. Astruc, C. R. Acad. Sci. Sér IIc, 1 (1998) 21.

[55]A. Altomare, M.C. Burla, M. Camalli, G. Cascarano, C. Giacovazzo, A. Guagliardi, A.G.G. Moliterni, G. Polidori, R. Spagna, J. Appl. Crystallogr. 32 (1999) 115. 
[56] G.M. Sheldrick, Acta Crystallogr. A64 (2008) 112-122.

[57]L.J. Farrugia, J. Appl. Crystallogr. 45 (2012) 839-854.

[58] O.V. Dolomanov, L.J. Bourhis, R.J. Gildea, J.A.K. Howard, H. Puschmann, J. Appl. Crystallogr. 42 (2009) 339-341. 